\section{Cosmic Dust}

山越和 雄

“Cosmic Dust” (宇宙塵) は, 通常,「星間塵」) と 「感星間塵」゙を総称したものであって，地球に突入し てくるものはさらに，「流星塵」3)，「慧星塵」4または 「微隕石 ل5) といった名称も使われている。また，形状 から「球粒」あ)とよばれることもある。

星間蝔は, 初め, 星の光の吸収からその存在が認識 され, さらに星の光の偏光や, 最近は赤外線観測から 特殊な星の周囲に存在することが観測されるようにな った7。主として電波望遠鏡で観測される星間分子, 原子 ${ }^{8)}$ 之並んで，星間塵は，星の誕生と消隇に密接な 関俰をもっている。赤外線星の観測から波長 $10.3 \mu \mathrm{m}$ に放出ピークが認められ，おの打のケイ酸塩と氷によ るものと考兄られているが，一般に観測から星間塵の 生成条件や組成を詳しく調べるのは困難なので, dust の生成に関する室内実験も行われている9 。

つぎに，惑星間塵として観測されるものは，「黄道 光」や黄道上での対日点にみられる「対日照」とよば れる現象で，黄道面に沿って dust が分布したのが, 太陽光を反射して見えるものである。これょり太陽系 内の dust の空間分布が推定できる ${ }^{10)}$ 。

惑星間塵は，太陽の重力と同時に，光の圧力を受け 太陽の周囲をヶプラー運動しているが, 光はdustの, 太陽に向いた面で受けながら，上昇した温度による熱 輻射は等方的であることから，しだいに回転にブレー キがかかり，だんだんと太陽に向かって落下してい く。この効果を Poynting Robertson 効果とよぶが11), これにより dust には寿命が生ずる。逆にいえば, dust はつねに供給されているのかといら興味ある命 題が提起される。小惑星带や彗星 ${ }^{122}$ からの供給や，太 陽系外からの補給が考兄られる。とくに後者は，太陽 系内での同位体比組成とは異なった值をもった試料 ${ }^{33}$ や，「消隇核種」とよばれる比較的短い半隇期をるっ た放射性核種の検出などの研究を通じて，その証明が 試みられている。

地球の大気圈外での dust の観測は，ロケットや人 工衛星によって種々試みられてきた。最初はマイクロ フォン式の検出器が用いられたが, ノイズが多いの で，薄膜のコンデンサ型のものが使われる。dust が 2 枚の薄膜を貫通してその時間の差から速度と, また 同様のものを多数配置させることによって, 到来角度 を求めることができる ${ }^{14)}$ 。この種の検出器の校正のた めに, 人工ダストの加速器も運転されている。

地球の大気圈内での dust の捕集は, 人工塵の混入 を避ける意味で気球，高山衫，極地方などで行われ る。

この場合, dust が大気圈に突入して溶融し，定常 落下速度になって凝固したプロセスを考兄て，丸い形
に着目して，顕微鏡下で微小球粒を pick up して降 下率を求めたり，X線マイクロ分析による組成の研究 を行っているが，何分にも採取できる量が極端に少な く，まとめて宇宙線生成核種を測定するだけの分量を 集めるのは非常に労力を要する困難な仕事である。

深海底または極地方の氷層は，長期間にわたって静 穏に環境が保全されてきたこともあって，これらの球 粒を入手するのに適した試料を提供してくれる ${ }^{16)}$ 。堆 積物または皮層中の固形成分中に dust の降下した痕 跡を求めるには，火成岩組成に著しく欠如した元素

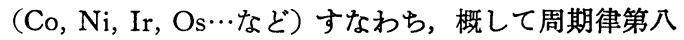
族の元素が試料に多く含まれていることを確認するこ

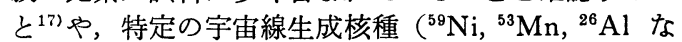
ど）を，それらを含む化学種 (元素) ごと抽出し，低レ ベル計測を行ら方法 ${ }^{18)}$ ，または，筆者らのグループで 進めている，これら球粒の大量採取と低レベル計測の やり方がある ${ }^{19 \%}$ 。またさらに，球粒 1 個ごとに，第入 族元素を放射化分析で検出し, 地球外起源のはっきり したものについて, 高感度質量分析計で, 宇宙線生成核 種の検出や年代測定を行うやり方も始められている。

宇宙塵の研究は, 天文観測で, 飛翔体に上る検出 で，また深海底や水層試料からの球粒について，怙の 颃の独特のやり方で進められている。近い将来, これ らの分野で知識を深め, 共通の「言葉」で比較検討が できるよらにするのがわれわれの課題であろう。また 同時に, 月, 惑星試料と並んで隕石との, 物質レベル での関係を明らかにするのが学問の向から方向であろ らと思われる。

\section{註と文 献}

1) interstellar dust

2) interplanetary dust

3) meteoric dust

4) cometary dust

5) micrometeorite

6) spherule

7) F.J. Low, et al.: Astrophys. J., 160, 531 (1970)

8) G.B. Field: ibid., 187, 453 (1974)

9) F. Kamijo, et al.: Icarus, 26, 102 (1975)

10) A.C. Levasseur, et al.: Space Res., XV, 573 (1975)

11) S.P. Wyatt, Jr., et al.: Astrophys. J., 111, 134 (1950)

12) D.W. Hughes: Space Res., XV, 565 (1975)

13) R.N. Clayton, et al.: Science, 182, 485(1973)

14) J.W. Rhee, et al.: Nature, 252, 555 (1974)

15) O. Vittori A: J. Geophys. Res., 75, 371 (1970)

16) H.T. Millard, Jr., et al.: ibid., 75, 2125(1970)

17) J.L. Barker, Jr., et al.: Geochim. Cosmochim. Acta, 32, 627 (1968)

18) J.L. Reyss, et al.: Science, 193, 1119 (1976)

19) K. Kobayashi, et al.: Proc. Int. Conf. Cosmic Rays, MG-3-27 (1975)

（東京大学宇宙線研究所） 


\author{
液体シンチレーションに括ける \\ 色クエンチングの機構
}

\section{石 河 寛 昭}

シンチレーター溶液が放射線エネルギーを吸収する と，溶質から光子が放出される。この光子のエネルギ 一の值はある幅をもっているが，これは溶質分子の第 1 電子励起隼位から基底状態に打ける多くの振動準位 にエネルギー遷移が生ずるためである。したがって, 溶質の発光スペクトルはある波長領域にわたる広がり をなしている。

この発光スペクトルの波長領域に吸収スペクトルを もつ物質がシンチレータ一溶液中に存在すると色クエ ンチングの現象が起こる。すなわち, 溶質から放出さ れた光子は光電子増倍管の光電面に向かって運動する が，光子の一部は光電面に到達する以前に色クエンチ ヤ一分子と会合して吸収される。色クェンチングの程 度は，1）光子の発生点から光電面までの経路の長さ, 2）色クエンチャ一の吸収スペクトルの波長領域，3） 色クエンチャ一の分子吸光係数などによって左右され る。色クエンチャーは光子エネルギーを吸収して励起 状態になるが，基底状態に遷移するさいの放出エネル ギーはほとんど熱として失われる。

溶質の発光スペクトルの波長領域は溶質の種類によ って異なり，第 1 溶質では大体 $3,000 \sim 4,500 \AA ̊$ ，第 2 溶質では $3,500 \sim 5,000 \AA ̊$ 付近である ${ }^{1}$ 。したがって, このあたりに吸収スペクトルをもつ物質は色クェンチ ングを起こす。

測定試料が着色している場合には色の種類によって 吸収スペクトルの位置が異なる。赤色や黄色を呈する 物質はクエンチングが強く2)(青色はかなり弱い)，こ れらの吸収スペクトルは可視部の短波長側に存在し, 第 1 溶質よりも第 2 溶質の発光スペクトルと重冨性が 大きい。これらの関係は図によって明らかである。し たがって，測定試料が黄色または赤色を帯びている場 合には，一般に第 2 溶質を使用しない注らが色クエン チングの影響を減少させることができる3。

着色物質による色クエンチングの場合には，過酸化

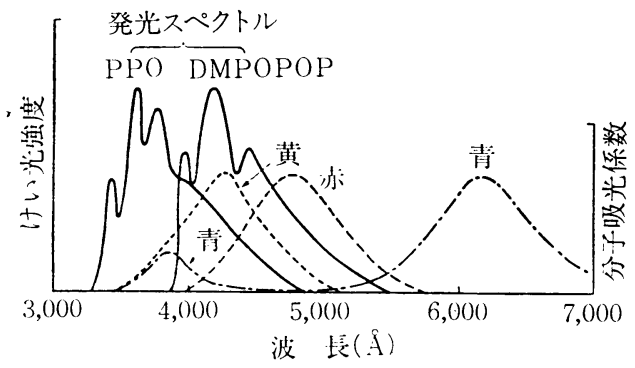

図 溶質の発光スペクトルと色の吸収スペクトル との関係
水素4), 過酸化ベンゾイル5) 7), 水素化ホウ素ナトリウ $\Delta^{8)}$ などで試料を脱色すると色クエンチングは除かれ る。しかし，脱色剈を加えたために化学クェンチング の原因となることがある。

測定試料が無色透明であっても，この試料が溶質の 発光スペクトルの位置に吸収スペクトルを有している ことがある。この場合にも当然色クエンチングが生ず るので, 色クエンチングは光学的クエンチングともよ ばれる。一般に，不飽和結合をなしている分子は $\pi$ 電 子をもっており，このような物質の吸収スペクトルは 比較的長波長の近紫外部に存在する。一方， $\pi$ 電子を もたず， $\sigma$ 電子だけを有する分子の吸収スペクトルは かなり短波長側に存在しているので，色クエンチング を起こすことは少ない。

色クエンチングを生じている場合のパルス波高分布 曲線は, 化学クエンチングを起こしている場合よりも 広範囲であり 9 ，色クエンチングの現象を計算により 理論的に解析した場合にも同様の結果が得られてい る $^{10)}$ 。

クエンチャーには色クェンチングと化学クエンチン グの両方を同時に起こすものがかなり多いが，色クェ ンチングの機構を考慮した特殊な測定ジオメトリーを 用いると, 両クエンチングのらちから色クエンチング だけを取り出すことも可能である11)。

\section{文献}

1) I.B. Berlman: Handbook of Fluorescence Spectra of Aromatic Molecule, Academic Press, New York (1971)

2) J.C. Turner: Sample Preparation for Liquid Scintillation Counting, RCC Review 6, Amersham (1971)

3）石河寬昭：液体シンチレーション測定法, p.101 南山堂 (1977)

4) R.J. Herberg: Anal. Chem., 32, 42 (1960)

5) D.L. Hansen and E.T. Bush: Anal. Biochem., 16, 466 (1966)

6) J. Winkelman and G. Slater: ibid., 20, 365 (1967)

7) H.J. Laurencot and J.L. Hempsted: Organic Scintillators and Liquid Scintillation Counting, p. 635, Academic Press, New York (1971)

8) H.M. Fales: Atomlight, 25, 8 (1963)

9) M.P. Neary and A.L. Budd: Current Status of Liquid Scintilation Counting, p.273, Grume \& Stratton, New York (1970)

10) F.E.L. Ten Haaf: Liquid Scintillation Counting, Vol. 2, p.39, Heydon \& Son Ltd., London (1972)

11) M. Takiue and H. Ishikawa: Nucl. Instr. Meth., 118, 51 (1974)

（日本原子力研究所RI ・ 原子炉研修所） 


\section{（1）基礎打よび一般}

\section{$(1 \cdot 1)$ 物 理}

14382 Isomer Yield Ratios of ${ }^{132 m} \mathrm{I}$ and ${ }^{134 m} \mathrm{I}$

N. Lavi, et al.: J. Inorg. Nucl. Chem., 38, (12) 2133 (1976)

14383 Decay of ${ }^{113} \mathrm{Sn}$ to Levels of ${ }^{113} \mathrm{In}$

A. A. Delucchi, et al.: ibid., 38,(12)2135(1976)

14384 Positron Decay in Benzene Solutions of $3 d$ Transition Metal Acetylacetonates and Dipivaloylmethanates

K. Endo, et al.: J. Phys. Chem., 80, (14) 1540 (1976)

14385 Studies of Molecular Complex Formation by Positron Annihilation Techniques Yan-Ching Jean, et al.: ibid., 80, (15) 1693 (1976)

14386 Neutron Capture Cross Sections from 0.1 to $3 \mathrm{MeV}$ by Activation Measurements

M. Lindner, et al.: Nucl. Sci. \& Eng., 59, 381 94 (1976)

14387 Energy Spectra of Secondary Neutrons from the ${ }^{239} \mathrm{U}(n, 2 n)$ and $(n, 3 n)$ Reactions M.S. Caner, et al.: ibid., 59, 395 405 (1976)

14388 Cross Sections and Resonance Integrals for the Fission of ${ }^{239} \mathrm{Pu}, \mathrm{Am}, \mathrm{Cm}$, and ${ }^{249} \mathrm{Cf}$

K.D. Zhuravlev, et al.: Soviet Atomic Energy, 39, (4) 907 (1975)

14389 Ratio of Radiative Capture and Fission Cross Sections for ${ }^{239} \mathrm{Pu}$ at Neutron Energies of $0.2-30 \mathrm{keV}$

A.A. Bergman, et al.: ibid., 39,(4) 916(1975)

14390 Cross Section for the Fission of ${ }^{240} \mathrm{Pu}$ by Neutrons from a Nuclear Explosion

É.F. Fomushkin, et al.: ibid.,39, (4) 921(1975)

14391 Characteristics of the $\gamma$ Activation of Light Elements

M.G. Davydov, et al.: ibid., 39,(5)1006(1975)

14392 Neutron Resonances in ${ }^{244} \mathrm{Cm},{ }^{245} \mathrm{Cm},{ }^{246} \mathrm{Cm}$, and ${ }^{248} \mathrm{Cm}$

T.S. Belanova, et al.: ibid., 39,(5)1020(1975)

14393 Nonsteady-State Space-Energy Spectrum of Neutrons in a Heavy, Weakly Inhomogeneous Medium, Allowing for Neutron Capture E.V. Metelkin: ibid., 40, (1) 45 (1976)

14394 Experiments on Cooling by Electrons G.I. Budker, et al.: ibid., 40, (1) 50 (1976)

14395 Universal Absorption Curves for a Sinusoidally Modulated Electron Beam

R.Ya. Strakovskaya, et al.: ibid., 40, (1) 59
(1976)

14396 Determination of the Half-Life of ${ }^{238} \mathrm{Pu}$ V.G. Polyukhov, et al.: ibid., 40,(1) 66(1976)

14397 The High-Temperature Thermal Diffusivity and Electrical Resistivity of Ytrium and Gadolinium

I.I. Novikov, et al.: ibid., 40, (1) 69 (1976)

14398 Efficiency for Conversion of Electrons into Positrons at $20-70 \mathrm{MeV}$

V.A. Tayurski: ibid., 40, (1) 80 (1976)

14399 Dependence of Asymmetry in the Photofission of ${ }^{233} \mathrm{U}$ and ${ }^{239} \mathrm{Pu}$ on the Maximum Bremsstrahlung

M.Ya. Kondrat'ko, et al.: ibid., 40, (1) 83 (1976)

14400 Measurement of the Energy Dependence of $\eta{ }^{233} \mathrm{U}$ in the $0.02-1-\mathrm{eV}$ Region

V.A. Pshenichnyi, et al.: ibid., $\quad 40$, (1) 89 (1976)

$$
\text { (1.2) 化学 }
$$

14401 Perturbed $\gamma-\gamma$ Directional Correlations and the Complex Chemistry of Hafnium and Tantalum

M.De. Bruin, et al.: J. Inorg. Nucl. Chem., 38, (12) 2149 (1976)

14402 The Helium Ion-indused Fission of Enriched Isotopes of Mercury and Tungsten at Moderate Bombarding Energies

E.F. Neuzil: ibid., 38, (12) 2153 (1976)

14403 Proton Induced Reactions of ${ }^{151} \mathrm{Eu}$ and ${ }^{153} \mathrm{Eu}$ up to $E_{p}=52 \mathrm{MeV}$

K. Komura, et al.: ibid., 38,(12) 2157 (1976)

14404 Excitation Functions and Yields of $(d, n)$ and $(d, 2 n)$ Reactions on Natural Molybdenum Z. Randa, et al.: ibid., 38, (12) 2289 (1976)

14405 Gas to Liquid to Solid Transition in $\mathrm{Ha}$ logen Hot Atom Chemistry. 3. Evidence for an Excited Reaction Intermediate in the ( $\boldsymbol{n}$, $r)$-Activated Reactions of Iodine with Acetylene

Kar-Chun To, et al.: J. Phys. Chem., 80,(13) 1411 (1976)

14406 Measurement of the Capture-Fission CrossSectional Ratio $\alpha$ for ${ }^{235} \mathrm{U}$ in the Filtered Neutron Beams of the Obninsk Nuclear Power Station Reactor

V.G. Dvukhsherstnov, et al.: Soviet Atomic Energy, 39, (2) 670 (1975)

14407 A Sensitive Method for Determining the Elements of the Actinium Series V.M. Kuptsov: ibid., 39, (2) 701 (1975) 
14408 ( $n, p)$ Cross Sections for ${ }^{27} \mathrm{Al},{ }^{28} \mathrm{Si},{ }^{81} \mathrm{P}$, ${ }^{85} \mathrm{Cl},{ }^{39} \mathrm{~K}$, and ${ }^{52} \mathrm{Cr}$ at $14.1 \mathrm{MeV}$

D.V. Aleksandrov, et al.: ibid., 39, (2) 736 (1975)

14409 Stimulating Isotopically Selective Heterogeneous Reactions with Laser Light

V.D. Borman, et al.: ibid., 40,(1) 78 (1976)

$$
\text { (1.3) そ の 他 }
$$

14410 A Theoretical Calculation of the Equilibrium Constant for the Isotopic Exchange Reaction between $\mathrm{H}_{2} \mathrm{O}$ and $\mathrm{HD}$

Richard D. Bardo, et al.: J. Phys. Chem., 80, (1) 1068 (1976)

\section{（2）線源とその利用}

\section{（2・1）線源・加速器・照射装星}

14411 Reliability of Electron Accelerators for Radiochemical Devices

Yu.D. Kozlov: Soviet Atomic Energy, 39,(4) 900 (1975)

14412 Self-Acceleration Experiment of a Strong Electron Beam in a Ferrite Accelerating Structure

V.V. Zakutin, et al.: ibid., 40, (1) 63 (1976)

(2・2） ラジオグラフィ

14413 Measurement of Composite Ply Orientation Using a Radiographic Fringe Technique

R.L. Crane: Mater. Eval., 34, 79 80 (1976) （2·3）応用㖕測および装供機器

14414 Mössbauer Study of the Effects of Electron Scavenger on the Stabilisation Forms of Iron Atoms Produced at the Decay of ${ }^{57} \mathrm{Co}$ in the Glass Matrices

Yu.D. Perfiliev, et al.: J. Inorg. Nucl.Chem., 38, (12) 2145 (1976)

14415 Mössbauer Study of Equilibrium Constants of Solvates. 2. Determination of Some Solvation Parameters of Tin Tetrahalides

A. Vértes, et al.: J. Phys. Chem., 80, (12) 1314 (1976)

14416 Determination of Hydrogen Density in Matter and Hydrogen Interaction with Metals from Neutron Transmission

M.S. Gusarov, et al.: Soviet Atomic Energy, 39, (2) 724 (1975)

\section{（3）放射線照射効果}

\section{(3.1) 物理的効果}

14417 Using the Method of Proton Backscattering for the Analysis of Radiation Defects in Ion Crystals
L.K. Mamaev, et al.: Soviet Atomic Energy., 39, (2) 685 (1975)

14418 Calculation of Gamma-Ray Incoherent Scattering Cross Section by Statical Simulation of the Transport Process

O.S. Marenkov: ibid., 39,(2) 722 (1975)

14419 Annealing Behavior of Pores in $(n, \alpha)$ Absorbers after Neutron Irradiation

S.S. Kiparisov, et al.: ibid., 39,(2) 729 (1975)

14420 Penetration of Niobium by $\mathrm{D}^{+}$Ions and Outgassing of Deuterium

A.A. Pisarev, et al.: ibid., 39,(3) 803 (1975)

14421 Dependence of $\bar{\nu}$ on Neutron Energies up to $5 \mathrm{MeV}$ for ${ }^{233} \mathrm{U},{ }^{238} \mathrm{U}$, and ${ }^{239} \mathrm{Pu}$

B. Nurpeisov, et al.: ibid., 39.,(3) 807 (1975)

14422 Determination of Cross Sections for Inelastic Processes and the Formation of $443 \mathrm{MeV}$ $r$ Quanta during the Interaction of Carbon with the Neutrons from a $\mathrm{T}(d, n)^{4} \mathrm{He}$ Reaction

V.T. Shchevolev, et al.: ibid.,39, (3)814(1975)

14423 Angular Distributions of Electrons Reflected from a Metal Surface for Oblique Incidence

V.P. Kovalev, et al.: ibid., 39,(3) 829 (1975)

14424 Time Characteristics of the Distribution of Scattered Gamma Rays in a Uniform Air Medium

S.N. Sidneva, et al.: ibid., 39, (3) 832 (1975)

14425 Spectral Distribution of the Albedo of ${ }^{137} \mathrm{Cs}$ $\gamma$ Radiation for a Two-Layer Medium with a Cylindrical Interface

Yu.B. Davydov, et al.: ibid., 39, (4)901(1975)

14426 Elemental Analysis of Boron Carbide and Initial Components by Proton-Induced X Rays A.G. Strashinskii, et al.: ibid., 39, (4) 904 (1975)

14427 Evolution of Hydrogen from Proton-Irradiated Construction Materials

Yu.P. Vasin, et al.: ibid., 39, (4) 919 (1975)

14428 Tissue Doses from Neutron Radiation

V.N. Ivanov, et al.: ibid., 39,(5) 1006 (1975)

14429 Simulation of Processes in Heavy Charged Particle Tracks by Pulsed Irradiation of Solids with High-Density Electron Beams

D.I. Vaisburd, et al.: ibid., 39,(5) 1016(1975)

14430 Radiation Hardening of Graphite Parts with Stress Raisers

Yu.S. Virgil'ev, et al.: ibid., 39,(6)1093(1975)

(3·2）単体およひ無機化合物

14431 Dry Electron Yields and Localization in 
Pulse-Irradiated Water and Heavy Water Cz. Stradowski, et al.: J. Phys. Chem., 80, (10) 1054 (1976)

14432 Spectrophotometric Studies of the Radiolysis of Liquid Ammonia

M.O. Delcourt, et al.: ibid., 80,(10) 1101(1976)

14433 Pulse Radiolysis of Aqueous Cyanide Solutions. Kinetics of the Transient $\mathrm{OH}$ and $\mathrm{H}$ Adducts and Subsequent Rearrangements

Hch. Büchler, et al.: ibid., 80,(14) 1549(1976)

14434 Oxygen Radiolysis by Modulated Molecular Beam Mass Spectrometry

Valerie R. Kruger, et al.: ibid., 80, (15) 1676 (1976)

14435 Pulse Radiolysis Studies of Uranium (VI), Neptunium(V), Neptunium( $\nabla$ ), and Plutonium (VI) in Aqueous Perchlorate Media

J.C. Sullivan, et al.: ibid., 80,(15) 1684(1976)

14436 Radiolysis of Acid Solutions of Potassium Iodate in Contact with a Solution of Tri- $n$ Butyl Phosphate in Hexane

E.V. Barelko, et al.: Soviet Atomic Energy, 39, (5) 988 (1975)

\section{（3・3） 有機化合物}

$14437 \gamma$-Radiolysis Effects on Methylpyridine Derivatives of Iron Thiocyanate

D.J. McIvor, et al.: J. Inorg. Nucl. Chem., 38, (12) 2275 (1976)

14438 Radiation Decomposition of $p$-Nitroperoxybenzoic Acid in Solution

Edgar Heckel: J. Phys. Chem., 80,(12) 1274 (1976)

14439 Spectroscopic Study on Aggregate Ion Radicals of Naphthalene and Pyrene in $\gamma$ Irradiated Alkane Glasses

A. Kira, et al.: ibid., 80,(13) 1445 (1976)

14440 Pulse Radiolysis of Ethyl Acetate and Its Solutions

G. Ramanan: ibid., 80,(14) 1553 (1976)

14441 Pulse Radiolytic Investigations of Peroxy Radicals Produced from 2-Propanol and $\mathrm{Me}$ thanol

Yael Ilan, et al.: ibid., 80, (14) 1558 (1976)

14442 Pulse Radiolytic Investigations of Peroxy Radicals in Aqueous Solutions of Acetate and Glycine

Sara (Dinur) Abramovitch, et al.: ibid., 80, (14) 1562 (1976)

14443 Nanosecond Pulse Radiolysis of Hydrazine J. Delaire, et al.: ibid., 80, (15) 1687 (1976)

\section{（3.4）高分子亡重合}

14444 ESR Study of Radiation-Induced Polymerization of Methyl Methacrylate on Solid Surfaces

H. Yoshioka, et al.: J. Polymer Sci., (Polymer Chem.), 14,(6) 1331 (1976)

14445 Radiation-Induced Polymerization of Acrylic Acid in Aqueous Solution

M.B. Huglin, et al.: ibid., 14,(6) 1363 (1976)

14446 Study of Radiation-Induced Polymerization of Vinyl Monomers Adsorbed on Inorganic Substances. VII. Effect of Pretreatment Temperature of Silica Gel on Styrene-Silica Gel System

K. Fukano, et al.: ibid., 14, (7) 1743 (1976)

14447 Kinetics of Radiation-Induced Postpolymerization of Trioxane in the Solid State M.L. Sagu, et al.: ibid., 14, (7) 1815 (1976)

14448 Influence of $\gamma$-Irradiation in the Molten State on the Dynamic Mechanical $\beta$ Relaxa. tion and on the Thermally Stimulated Depolarization Currents of Polyethylene

M. Pineri, et al.: J. Polymer Sci. (Polymer. Phys.), 14, (7) 1325 (1976)

\section{（4）トレーサー利用 \\ (4・1）物理的トレーサー}

14449 Physicochemical 'Bases and Calculation of Vaporization Processes for Highly Active Nitric Acid Solutions

A.N. Efimov, et al.: Soviet Atomic Energy, 39, (6)1074 (1975)

\section{（5）分 析 \\ (5.1) 放射化分析}

14450 A Simple Neutron Activation Method for the Determination of Mercury at ppb Level in Wheat Flour

H. Polkowska-Motrenko, et al.: Radiochem. \& Radioanal. Lett., 26, (3) 217 (1976)

14451 Determination of Silicon in Iron and Steel by $14 \mathrm{MeV}$ Neutron Activation and High Resolution Gamma-spectrometry

J.M. Chatterjee, et al.: ibid., 26,(4) 251(1976)

14452 Multielement Photon Activation Analysis of Rock Materials with $30 \mathrm{MeV}$ Bremsstrahlung

N. Sato, et al.: Radiochim. Acta, 21, 63(1974)

14453 Determination of Lanthanum in the Presence of Uranium by Neutron Activation Analysis Using High Resolution Gamma Spectrometry 
N. Lavi: ibid., 21, 73 (1974)

$$
\text { (5.4) そ の 他 }
$$

14454 Analytical Determination of Impurity Anions in Ionic Salts Using the Ionizing Radiation

V.I. Spitsyn, et al.: J. Radioanal. Chem.,30, 451 (1976)

14455 Determination of the Activity Product of Compounds Based on Microquantities of Radioactive Elements

N.B. Mikheev, et al.: idid., 30, 527 (1976)

14456 Determination of Mercury by Replacement of Thallium in Thallium-204 Labelled Thallium (1) Sulphide

V.R.S. Rao, et al.: Radiochem. \& Radioanal. Lett., 24, (4) 275 (1976)

14457 Determination of Deuterium in Water by a Thermometric Method

J. Cabicar: ibid., 24, $(5,6) 341$ (1976)

14458 Determination of Transuranium Elements in Nuclear Weapon Debris

R.N. Khandekar: ibid., 25, (2) 77 (1976)

14459 The Use of ${ }^{204}$ Thallous Chromate Columns for the Determination of Lead

V.R.S. Rao, et al.: ibid., 25, (4) 223 (1976)

14460 Separation and Determination of ${ }^{134} \mathrm{Cs}$ and ${ }^{137} \mathrm{Cs}$ Using Ammonium Molybdate-Silica Gel System for the Burn-up Calculation of Nuclear Fuel

F. Šebesta, et al.: ibid., 25, (4) 237 (1976)

14461 Analytical Methods for Determining the Distribution of ${ }^{32} \mathrm{P}$ Species in Neutron Irradiated Chlorides

A.G. Maddock, et al.: ibid., 25, $(5,6) 293$ (1976)

14462 Isotope X-ray Fluorescence Method for Determination of REE in Tungsten Bronzes $\mathrm{Me}_{\mathbf{x}} \mathrm{WO}_{3}$

A. Gçsicki, et al.: ibid., 26, (2) 117 (1976)

14463 Radiochemical Determination of Methylmercury Chloride. Pari 1. Isotope Exchange in Sulphuric Acid Medium

J. Stary, et al.: ibid., 26, (3) 193 (1976)

14464 Quelques separations radiochimiques effectuees sur l'etain irradie

A. Raitz, et al.: ibid., 26, (3) 205 (1976)

14465 Measurement of ${ }^{131} \mathrm{I}$ by a Liquid Scintillation Method

Š. Palágyi, et al.: ibid., 26, (4) 269 (1976)

\section{（7）同位体の製造・分離 (7·2） 標識化合物}

14466 Synthesis of Ethambutol $1{ }^{14} \mathrm{C}$ Dihydrochlo- ride [(十)-N, $\mathrm{N}^{\prime}$-Bis(1-Hydroxy-2-Butyl)-Ethylene-U. ${ }^{14} \mathrm{C}$-Diamine Dihydrochloride]

F.N. Shirota, et al.: J. Labelled Comp. \& Radiopharmc., 11, (3) 457 (1975)

14467 Labeled Metabolites of Polycyclic Aromatic Hydrocarbons III. 3-, 7-, and 9-Hydroxybenzo [a] Pyrenes-G- ${ }^{3} \mathrm{H}$

W.P. Duncan, et al.: ibid., 11, (3) 461(1975)

14468 Synthesis of Geraniol-9- ${ }^{14} \mathrm{C}$. Methods for Obtaining Labelled Geraniols Free of Citronellol

S.J. Rajan, et al.: ibid., 11, (4) 467 (1975)

14469 Preparation of Tritium-labeled 2,4-Dichlorophenyl Pyrrolidinecarboxylate

M. Hamada, et al.: ibid., 11, (4) 477 (1975)

14470 Synthesis of $1,2,6,7 \cdot{ }^{14} \mathrm{C}$-Chelidonic Acid

J. Bergman, et al.: ibid., 11, (4) 485 (1975)

14471 Synthesis of Hexalabeled Thymine and Thymidine

J.A. Lawson, et al.: ibid., 11, (4) 489 (1975)

14472 Radiolysis of ${ }^{14} \mathrm{C}$ - and ${ }^{3} \mathrm{H}$-Labelled Thymidine

J. Kopoldavá, et al.: ibid., 11, (4) 501 (1975)

14473 The Synthesis and Purification of $8{ }^{14} \mathrm{C}$ Theophylline

S.M. Lohmann, et al.: ibid., 11, (4) 515(1975)

14474 Préparation du Phenyl-3 Propene-2 OL-1 ${ }^{14} \mathrm{C}-3$ (Alcohol Cinnamique ${ }^{14} \mathrm{C}-3$ )

N.H. Nam, et al.: ibid., 11, (4) 521 (1975)

14475 Synthesis of Carbon-13 Enriched Nitrobenzene

G.L. Swartz, et al.: ibid., 11, (4) 525(1975)

14476 A Gas-chromatographic Method for the Preparation of ${ }^{14} \mathrm{C}$-Labelled Vinyl Chloride

E.R. Wagner, et al.: ibid., 11, (4) 535 (1975)

14477 Tritium Recoil Labelling of Phenylacetic Acid

A. Dubey, et al.: ibid., 11, (4) 543 (1975)

14478 The Synthesis of Deuterium Carbon-14 and Carrier-free Tritium Labeled Cannabinoids C.G. Pitt, et al.: ibid., 11, (4) 551 (1975)

14479 Synthesis of Antheridiol- $\left(22,23-{ }^{3} \mathrm{H}\right)$

T.C. McMorris, et al.: ibid., 11, (4)577(1975)

14480 An Improved Synthesis of 5-Fluorouracil$6{ }^{-14} \mathrm{C}$

C.W. Perry, et al.: ibid., 11, (4) 583(1975)

14481 Synthesis of Betamethasone- $1,2-{ }^{3} \mathrm{H}_{2} \quad 17$, Benzoate

T. Kobari, et al.: ibid., 11, (4) 591 (1975)

14482 Synthesis of Deuterated Analogs of Chlo- 
romethyl Methyl Ether

J. Gal: ibid., 11, (4) 597 (1975)

14483 Preparation of 'Tritium Labeled Diphenylhydantoin of High Specific Activity

J.A. Kapler: ibid., 11, (4) 601 (1975)

14484 A Convenient Synthesis of Ethyl- ${ }^{14} \mathrm{C}$ Isocyanate

D.T. Witiak, et al.: ibid., 11, (4) 605 (1975)

14485 A Simple Preparation of the Isotopically Substituted Methyl Acetates

M.A. Winnik, et al.: ibid., 11, (4) 609(1975)

14486 Synthesis of $p$-Substituted-Benzaldehyde$\alpha-d$

T.T. Su: ibid., 11, (4) 613 (1975)

14487 2-Deuteromethylation of Ketones

B. Fuchs, et al.: ibid., 12, (1) 3 (1976)

14488 Synthesis of ${ }^{14} \mathrm{C}$-labelled 4-Hydroperoxyisophosphamide, an Effective Anti-tumor Agent T. Nagasaki, et al.: ibid., 12, (1) 7 (1976)

14489 Synthesis of Deuterium and Tritium Labelled Derivatives of Maleopimaric Acid P.J. Ramm, et al.: ibid., 12, (1) 13 (1976)

14490 Synthesis of ${ }^{14} \mathrm{C}$-Desmethylene Aldrin, Desmethylene Dieldrin and Desmethylene Aldrin cis-and trans-dihydrodiols

M.P. Walker, et al.: ibid. 12, (1) 23 (1976)

14491 Synthese Assymétrique de la D(+)amphétamine $-{ }^{14} \mathrm{C}-7$ par 1'Intermédiare du Benzyl-2 methyl-2 dithianne-1,3

L. Pichart, et al.: ibid., 12, (1) 31 (1976)

14492 Synthesis of ${ }^{14} \mathrm{C}$-labelled 2,2-Dichloropropionic Acid

F.S. Tanaka, et al.: ibid., 11, (1) 41 (1976)

14493 A Quantitative Stereoselective Synthesis of Radiolabelled $\mathrm{PGF}_{2 x}$ from Arachidonate or $\mathrm{PGE}_{2}$

K.J. Stone, et al.: ibid., 12, (1) 53 (1976)

14494 The Synthesis of ${ }^{18} \mathrm{O}$ Multilabelled Anhydrous Nitric Acid

A.C. Scott, et al.: ibid., 12, (1) 63 (1976)

14495 Synthesis of Deuterium-labelled Drugs of Abuse for Use as Internal Standard in Quantification by Selected Ion Monitoring. I. Methamphetamine; 2,5-Dimethoxy-4-methylamphetamine(DOM); Phencyclidine(PCP); and Methaqualone

A.F. Fentiman Jr., et al.: ibid., 12, (1) 69 (1976)

14496 Synthese von Pulvinsäure- $\left[{ }^{14} \mathrm{C}\right], 4$-Hydroxypulvinsäure- $\left[{ }^{14} \mathrm{C}\right]$ und $4^{\prime}$-Hydroxy-pulvinsäure$\left[{ }^{14} \mathrm{C}\right]$

H.E. Noppel, et al.: ibid., 12, (1) 79 (1976)
14497 Specific ${ }^{14} \mathrm{C}$-labelled Surfactants. The Addi tion of Homogeneous Polyoxyethylene Glycols to $p$-(1,1,3,3-tetramethylbutyl)phenol F.S. Tanaka, et al.: ibid., 12, (1) 97 (1976)

14498 Specific ${ }^{14} \mathrm{C}$-labelled Surfactants. The Addition of Homogenous Polyoxyethylene Glycols to 2,6,8-Trimethyl-4-nonanol

F.S. Tanaka, et al.: ibid., 12, (1) 107(1976)

14499 Synthesis with Stable Isotopes: Acetic-1${ }^{13} \mathrm{C},-2-{ }^{13} \mathrm{C},-{ }^{13} \mathrm{C}_{2}$ and ${ }^{-12} \mathrm{C}_{2}$ Acids

D.G. Ott, et al.: ibid. 12, (1) 119 (1976)

14500 Specifically Tritiated Arene Oxides H. Yagi, et al.: ibid., 12, (1) 127 (1976)

14501 Synthesis of DL-Tyrosine-2'-t and Tyramine- $2^{\prime}-t$

P.W. Jeffs, et al.: ibid., 12, (1) 133 (1976)

14502 Synthesis of Cyclopropyl Cyanide-2,2-D W.B. Edwards III, et al.: ibid., 13, (1) 145 (1976)

14503 Labelled Metabolites of Polycyclic Aromatic Hydrocarbons II. 4,5-Dihydrobenzo a Pyrene 4-,5-epoxide-G- ${ }^{3} \mathrm{H}$ via cis-4,5-Dihydrobenzo a Pyrene-4,5-diol-G- ${ }^{3} \mathrm{H}$

K.C. Kolwyck, et al.: ibid., 12, (1) 153(1976)

14504 Labelled Polypeptides. V. Synthesis of $\alpha$ -

* Melanotropin Labelled with Tritium on the Tyrosine Residue, via the Dibromo Intermediate

K. Nikolics, et al.: ibid., 12, (2) 163 (1976)

14505 Synthesis and N-Methylation of $\beta-{ }^{14} \mathrm{C}-p$ Chloroamphetamine Hydrochloride

E.P. Burrows, et al.: ibid., 12, (2) 173(1975)

14506 Synthese von $\left[{ }^{14} \mathrm{C}\right]$ Propiramfumirat W. Maul: ibid., 12, (2) 181 (1976)

14507 Synthesis of N-Phenyl-2-[1,4,5,8- $\left.{ }^{14} \mathrm{C}\right]$ naphthylamine N-Phenyl-2-[8- $\left.{ }^{13} \mathrm{C}\right]$ naphthylamine and $\mathrm{N}-\left[\mathrm{U}-{ }^{14} \mathrm{C}\right]$ Phenyl-2-naphthylamine

+G.H. Walker, et al.: ibid., 12, (2) 199(1976)

14508 A High Yield Synthesis of C-14-Ringlabelled and C-14-Methyl-labelled N-Methyl$\mathrm{N}$-nitrosoaniline

C.J. Grandjean, et al.: ibid.,12, (2)207(1976)

14509 Preparation of Tritiated Substituted Estratrienes

A.D. Fraser, et al.: ibid., 12, (2) 213 (1976)

14510 Non Spécificité de Marquage dans le Cas de Tritiation par Déshalogénation Catalytique: Cas de la Papavérine

J. Devillers, et al.: ibid., 12, (2) 219 (1976)

14511 Preparation of ${ }^{3} \mathrm{H}$-labeled Ochratoxins

F.C. Chang, et al.: ibid., 12, (2) 231 (1976)

14512 Synthesis of ${ }^{14} \mathrm{C}$-labelled 2, 4, -Diamino- 
5-phenylthiazole Hydrochloride(Amphenazole)

J.G. Adams, et al.: ibid., 12, (2) 239 (1976)

14513 The Synthesis of 2-Chlorobiphenyl-1', $2^{\prime}$, $3^{\prime}, 4^{\prime}, 5^{\prime}, 6^{\prime}-{ }^{14} \mathrm{C}_{6}$

P.B. Reichardt, et al.: ibid., 12,(2) 243(1976)

14514 Labelling of a New Hypolipaemic Agent with Carbon-14, Preparation of 1,1-bis $[4-(1-$ Carboxy-1-methylpropoxy) phenyl]cyclohexane $-2-{ }^{14} \mathrm{C}$

A. Yoshitake, et al.: ibid., 12, (2) 247 (1976)

14515 Synthesis of High Specific Activity Benzo $[\alpha]$ pyrene-6- $t$ and Its K-Region Oxidized Derivatives

R.G. Harvey, et al.: ibid., 12, (2) 259 (1976)

14516 Tritium Nuclear Magnetic Resonance Spectroscopy. Part IV. Distribution of Tritium in $\left[\mathrm{G}-{ }^{3} \mathrm{H}\right]$ Phenylalinine and Other Amino Acids

J.M.A. Al-Rawi, et al.: ibid., 12, (2)265(1976)

14517 Labelled Metabolites of Polycyclic Aromatic Hydrocarbons IV. 7-Hydroxybenzo[a]pyrene $-7{ }^{13} \mathrm{C}$

W.P. Duncan, et al.: ibid., 12, (2) 275 (1976)

14518 Radiosynthesis of $(\rightarrow)$-Cocaine and Nor- $(-$ Cocaine Using Tritium-labelled Methanol W.W. Just, et al.: ibid., 12, (2) 281 (1976)

14519 Synthesis of Tritium-labelled $d, 1$-Coniine W.W. Just, et al.: ibid., 12, (2) 287 (1976)

14520 Tritium Nuclear Magnetic Resonance. Part V. Distribution of Tritium in Labelled Polycyclic Hydrocarbons

J.M.A. Al-Rawi, et al.: ibid., 12, (2)293(1976)

14521 Synthesis of ${ }^{14} \mathrm{C}$-labelled Tranexamic Acid [trans-amino-( ${ }^{14} \mathrm{C}$-methy])-cyclohexane Carboxylic Acid]

J. Lundström, et al.: ibid., 12, (2) 307 (1976)

14522 Darstellung von ${ }^{36} \mathrm{Cl}-$ Markiertem Chloroform

W. Dams, et al.: ibid., 12, (2) 311 (1976)

14523 The Synthesis of ${ }^{18} \mathrm{O}$-enriched $\mathrm{KO}_{2}$

I. Rosenthal: ibid., 12, (2) 317 (1976)

14524 Carbon-14 Ring Labelling of Some Methylxanthines of Pharmacological Importance

G. Ayrey, et al.: ibid., 12, (3) 323 (1976)

14525 Synthèse d'une Pyridazine d'Intérêt Thérapeutique, Marquée au Carbone 14: Dichlorhydrate de Morpholinoéthylamino-3 méthyl-4 phényl-6 pyridazine $-{ }^{14} \mathrm{C}-6$ (30,038 $\left.\mathrm{CB}\right)$

L. Pichat, et al.: ibid., 12, (3) 347 (1976)

14526 Synthesis of $\left[\gamma^{14} \mathrm{C}\right]-\gamma-\mathrm{Oxo}-2$-dibenzofuranbutanoic Acid (Furobufen) and 2-Dibenzofuranacetic carboxy ${ }^{-14} \mathrm{C}$ Acid
E.S. Ferdinandi: ibid., 12, (3) 357 (1976)

14527 Tritium Labelling of Ribonuclease by the Gas-exposure Method, as Improved by an Electric Discharge

M. Noyer, et al.: ibid., 12, (3) 365 (1976)

14528 Synthesis of Carbon-13 Labelled 6-Substituted Benzo (a) Pyrenes

R.E. Royer, et al.: ibid., 12, (3) 377 (1976)

194529 Synthesis of Labeled L-Cystinyl-bis-Lvaline and bis-6-(L-2-Aminoadipyl)-L-cystinyl -bis-L-valine

H. Vanderhaeghe, et al.: ibid.,12, (3)381(1976)

14530 Préparation d'Aldéhydes-éthyléniques Deuteries sur le Groupement Carbonyle

M. Dedieu, et al.: ibid., 12, (3) 389 (1976)

14531 Labelling of an Anti-inflammatory Agent with Carbon-14, Synthesis of 5-Methoxy-2methyl-1-(3,4-methylenedioxybenzoyl)indole$2-{ }^{14} \mathrm{C}-3$-acetic Acid

I. Nakatsuka, et al.: ibid., 12, (3) 395 (1976)

14532 A Convenient Procedure for Preparing Naltrexone-15,16- ${ }^{3} \mathrm{H}_{2}$ and Naloxone $-15^{-3} \mathrm{H}$ of High Specific Activity

G.A. Brine, et al.: ibid., 12, (3) 401 (1976)

14533 Syntheses of Radioactive and Stable Isotopelabelled 1-Ethyl-6, 7-methylenedioxy-4(1H)oxocinnoline-3-carboxylic Acids (Cinoxacin)

T. Nagasaki, et al.: ibid., 12, (3) 409 (1976)

14534 Synthesis of Tritium Labeled Mazindol H.A. Dugger, et al.: ibid., 12, (3) 429 (1976)

14535 Synthèse d'un Diurétique Marqué au Carbone 14: Acide Dichloro-2,3(thénoyl-2 $\left({ }^{14} \mathrm{C}=\right.$ O)) -4 phénoxy acétique (D.C.I. Acide Tiénilique)

M. Herbert, et al.: ibid., 12, (3) 437 (1976)

14536 Labeled Metabolites of Polycyclic Aromatic Hydrocarbons. V. trans-7,8-Dihydrobenzo (a) pyrene-7,8-diol-7- ${ }^{14} \mathrm{C}$ and $(t)-7 \alpha, 8 \beta$-Dihydroxy $-9 \beta, 10 \beta$-epoxy-7,8,9,10-tetrahydrobenzo (a) pyrene-7- ${ }^{14} \mathrm{C}$

D.J. McCaustland, et al.: ibid., 12, (3) 443 (1976)

14537 Synthesis of Pentachloronitrobenzene $-{ }^{14} \mathrm{C}_{6}$ R.E. Kadunce, et al.: ibid., 12, (3) 459(1976)

14538 Synthesis of 2,4-Diamino-6-piperidinylpyrimidine-3-oxide- $3^{\prime}, 4^{\prime}, 5^{\prime}-{ }^{3} \mathrm{H}(\mathrm{N})$ Tritiated Minoxidil

T.J. Gilbertson: ibid., 12, (3) 463 (1976)

14539 The Preparation of ${ }^{2} \mathrm{H}$ - and ${ }^{3} \mathrm{H}$ - Tertiary Amines. Catalytic Hydrogenation in the Presence of the N-Cyclopropylmethyl Group M.J. Rance, et al.: ibid., 12, (3) 467 (1976) 


\section{$\mathrm{RI}$ 農学・生物学利用文献抄録集 (121)}

文献トピックス

デンプンの放射線照射処理

\section{久 米民和}

デンプンは食糧原料のみならず，各種の工業原料， 医薬品原料として多くの分野で利用されている多糖類 である。デンプンの放射線処理による物理化学的諸性 質の変化についてはこれまでに数多くの研究がなされ ている。デンプンに放射線を照射した場合, 粘度やヨ ウ素親和力が低下寸ること, 分子の分解や開裂がおこ り，グルュース，マルトース，デキストリンなどの低 分子物質が生成すること, カルボキシル含量やカルボ ニル数の増加や $\mathrm{pH}$ の低下など種々の変化が抢こるこ とがよく知られている。デンプンへの放射線利用に関 する研究は目的によって2つに大別できる。

一つは工業用原料としてのデンプンの放射線改質に 関するものである。この分野では，デンプン分子にビ ニルやメタクリル酸メチル単量体などをグラフト共重 合1させることへの放射線の利用，あるいは照射によ るデンプンの低粘度化, 溶解度增加に着目した紙の裴 面コーティングやサイジングへの利用22,3) などが試み られている。これらデンプンの放射線処理を実用化す るためには，照射効果と同時に照射コストが重要な要 因となる。すでに米国に㧤いて芈用化されている多く の施設の例からのコスト試算によると，製品の性質に 関係なく $1 \not / \mathrm{Mrad} \cdot \mathrm{lb}$. 程度 (約 8 円 $/ \mathrm{Mrad} \cdot \mathrm{kg}$ ) といら 値が得られている4)。この結果から判断すると，放射 線処理法は他の物理的あるいは化学的処理法とコスト 的には十分競合できると考光られる。近年とくに石油 枯渴問題や公害問題とあいまって, 天然高分子である デンプンの有效利用が注目されて叔り，これら工業原 料用デンプン改質への放射線利用は実用化の期待され る分野であろう。

他の一つは食品材料としてのデンプンの放射線殺菌 と加工適性の改良に関するものである。デンプンの無 菌化は, 水産練製品, 乳幼児食, 病人食, 乾燥スープ などの食品や医薬品原料あるいは動物用飼料として用 いる場合にとくに重要な問題となってきている。デン プン中には糸状菌, 严硫酸澴元性の Clostridium 属, 好気性有芽胞紐菌の Bacillus 属なに゙が含ま饥ている が，污染度の著しいものでも $300 \mathrm{krad}$ の照射で十分衛 生的なデンプンが得られ占，デンプンの殺菌には放射 線処理が有効な手段であると考兄られている。またデ ンプンに完全殺菌線量である $5 \mathrm{Mrad}$ 程度の照射を行 らと, $\beta$-アミラーゼによる消化率の増大的, ラットに 対する飼料効率の向上?などが認められ，照射デンプ
ンを発酵，飼料，加工原料として用いる場合の加工適 正の向上も期待できる。これらは主としてトウモロコ シ，馬鈴薯などのデンプンを用いた場合の結果である が，アミロース含量の高いアミロメイズデンプンでは $\beta$-アミラーゼ分解率が照射により低下する ${ }^{8)}$ こる認 められて括り，デンプンの種類によってはその性質変 化が多少暴なることも考えられる。

一方，食品㳊射線を照射する場合には，工業用原 料の場合と異なり，照射食品の健全性を検討しなけれ ばならない。殺菌線量の $300 \mathrm{krad}$ 照射したデンプン では, 生成ラジカルは安全上問題とはなり得ない.9)と されている。また毒性物質が生成しないかとの観点か ら，近年アセトアルデヒド，アセトン，メタノールを はじめ種々の低分子化合物の同定・定量が行われてい $ろ^{10)}$ 。従来照射食品の健全性を検討するためには，主 として動物試験が行われてきたが，食品成分の純粋な 系比打る分解生成物の定性的・定量的分析絬果の利 用も最近試みられている11。これら安全性㳊関するデ 一タの蓄積により, 近い将来照射デンプンの健全性が 保証されるであるう。

なお，食品照射の央用化にさいしては，照射した食 品の検知手段を開発することも重要な問題となる。デ ンプンの場合には，照射により生成するマロンアルデ ヒドを定星することにより，照射後 1 年間は検知可能 である12)と報告されている。

\section{文献}

1）半田 隆, 大塚信好, 鮎川弥一：高化，28，464 (1971)

2) R.M.A. El Saadany, F.M. El Saadany and Y.H. Foda: Stärke, 26, 422 (1974)

3) B.T. Hofreiter and C.R. Russell: ibid., 26, 18 (1974)

4) D.E. Harmer and D.S. Ballantine: Chem. Eng., 78, (10) 91 (1971)

5) L. Saint-Lebe, A. Mucchielli, P. Leroy and H. Beerens: IAEA-SM-166/6, 155 (1973)

6）三品楇良，二国二郎：農化，33，931 (1959）

7）梅田圭司，早川清一，早川昭，豊囟英親，宮崎基 嘉：食研報告, No.25, 11 (1970)

8）渡辺幸雄, 綾野雄幸, 小原哲二郎：食品工誌, 23, 13 (1976)

9）並木満夫, 林建 樹, 亀田 消, 川岸舜朗：食 品工誌，20，478 (1973)

10) G. Berger, J.P. Agnel and L. Saint-Lebe: Stärke, 26, 185 (1974)

11) J.F. Diehl and H. Scherz: Int. J. Appl. Radiat. and Isotopes, 26, 499 (1975)

12) R.V. Winchester: Stärke, 26, 278 (1974) (日本原子力研究所高崎研究所) 


\section{Penicillium charlesii の細胞壁多糖}

The Occurrence of Ethanolamine and Galactofuranosyl Residues Attached to Penicillium charlesii Cell Wall Saccharides

J.E. Gander, F. Fang: Dept. Biochem., Col. Biol. Sci., Univ. Minnesota, St. Paul, Biochem. Biophys. Res. Commun., 71, (3) 719 25 (1976)

Penicillium charlesii 細胞壁サッカライドにェタ ノールアミンとガラクトフラノシル残基が存在するこ とを明らかにした。 ${ }^{3} \mathrm{H}$-あるいは ${ }^{14} \mathrm{C}$-エタノールアミ ン存在下で培養した $P$. charlesii の細胞壁を調整し た。細胞壁に取り込まれた放射能の約 $50 \%$ はアルカリ 可溶，アルコール不溶画分に検出された。この画分を ダンシル化後水解することによってダンシルエタノー ルアミンが得られたが，培養ろ液に検出されるぺプチ ドフォスフォガラクトマンナンと異なっており，ガラ クトフラノシルを含む細胞壁ポリマーであることが示 唆された。

（奥田）

\section{Shigella 毒素によるタンパク合成阻害}

Inhibition of in vitro Protein Synthesis by Shigella dysenteriae 1 Toxin

M.R. Thompson, M.S. Steinberg, P. Gemski, S. B. Formal, B.P. Doctor: Div. Biochem. Med. Commun. Disease and Immunol., Walter Reed Army Inst. Res., Wash., Biochem. Biophys. Res. Commun., 71, (3) 783 88 (1976)

Shigella dystenteriae (I) の毒素がタンパク合成 を阻害することを明らかにした。I より生産される毒 素をゲルろ過, 焦点電気泳動などによって精製した。 $\mathrm{ATP},{ }^{14} \mathrm{C}-ア ミ ノ$ 酸混合物, 酵母あるいはコウシ肝 tRNA，ラット肝上澄み酵素を反応させ，酸不溶性画 分の放射能から tRNA のアミノアシル化反応を測定 した。この活性は毒素により影響されなかったが，ア ミノアシル tRNA からリボソームあるいはポリソー ムへのアミノ酸転移反応は阻害された。毒素によるタ ンパク合成阻害には Diphtheria 毒素の場合と異なり $\mathrm{NAD}^{+}$を必要としなかった。

(奥田)

\section{9 栄養的 shift-up と大腸菌の伸長因子}

Synthesis of Messenger RNA Coding for Elongation Factors $G$ and Ts during Nutritional Shiftup in Escherichia coli

P.G.H. Barnsley, S.M. Boyle, B.H. Sells: Lab. Mol. Biol., Fac. Med., Mem. Univ. Newfoundland, Biochem. Biophys. Res. Commun., 71, (3) 817 25 (1976)

大腸菌を栄養的にshift-up した場合の伸長因子合成 について検討した。大腸菌を shift-up し，経時的に 試料を採り， ${ }^{14} \mathrm{C}$-lys で 1 分間標識したのち, ${ }^{12} \mathrm{C}-$ lys で40分 chase した。この培養と ${ }^{3} \mathrm{H}$-lys で数世代標識 した培養を混ぜ，リボソーム，伸長因子 $G ， T_{3}$ およ び可溶性タンパクを分離して各画分の放射能比 $\left({ }^{3} \mathrm{H} /\right.$ ${ }^{14} \mathrm{C}$ あるいは ${ }^{14} \mathrm{C} /{ }^{3} \mathrm{H}$ ) を測定した。その結果, shiftup するとほとんどただちにリボソームタンパクの合 成速度が増大したのに反し，Gおよび Ts の合成速度 は 5-10分の誘導期ののちに増大した。（奥田）

\section{0 冬コムギ芽生えの低温依存性 RNase}

Low-Temperature-Dependent Ribonuclease in Chromatin of Winter Wheat Seedlings

K. Sasaki, S. Sasaki: Dept. Botany, Fac. Sci., Hokkaido Univ., Sapporo, Biochem. Biophys. Res. Commun., 72, (3) 850〜58 (1976)

冬ュムギの芽生えのクロマチンに存在する低温依存 性 RNase について検討した。無菌的に発芽させた Triticum aestrium L. vc. Mukakomugi のクロマ チン（I）から RNaseを部分精製した。酵母 sRNA, 市販の ${ }^{14} \mathrm{C}-\mathrm{RNA}$ 括よびI あるいは RNase を反応さ せ, 酸不溶性放射能の減少から RNase 活性を測定し た。その結果，I には至適温度が約 $30^{\circ}$ の RNase のほ かに, 約 $15^{\circ}$ の RNase が検出され, 至適 $\mathrm{pH}$ は約 8.0 であった。また，低温依存性 RNase 活性はベントナ イトやDNA により阻害され, cAMPにより促進され， また，熱に不安定であった。
8161 DNA ポリメラーゼ $\boldsymbol{\alpha}$ の核における存在

Nuclear Localization of DNA Polymerase $\alpha$ in Xenopus laevis Oocytes

G. Martini, F. Tao, D.G. Attardi, G.P. TocchiniValentini: Lab. Cell Biology-C.N.R., Rome, Biochem. Biophys. Res. Commun., 72, (3) 875 79 (1976)

増殖細胞の DNA ポリメラーゼ（I）の80-90\%を 占める DNA ポリメラーゼ $\alpha\left(\mathrm{I}_{\alpha}\right)$ が細胞質䤉素とい われていたが，本研究で核に存在することが示され た。成長した雌 Xenopus laeris の卵巣から卵母細胞

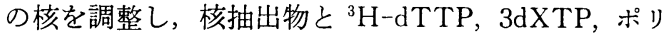
(A)-オリゴ（dT）あるいは活性化 DNA を反応させ, 酸不溶性放射能からI活性を求めた。その結果, 核抽 出物中の I 活性は N-エチルマレイミドで強く阻害さ れ，グリセロール勾配遠心にかけると $4 \mathrm{~S}$ マーカーよ り早く沈降し，ポリ(A)-オリゴ (dT) を鋳型としえな いことから，核抽出物中の I は I $\mathrm{I}_{\alpha}$ と考えた。

(奥田)

\section{2 cGMP 依存性タンパクキナーゼの解離}

Subunit Structure of Cyclic GMP-Dependent Protein Kinase from Guinea Pig Fetal Lung: Dissociation of Holoenzyme by Cyclic GMP and Histone

J.F. Kuo, J.G. Patrick, V.L. Seery: Dept. Pharmac. and Biochem., Emory Univ. Sch. of Med. Atlanta, Biochem. Biophys. Res. Commun., 72, (3) $996 \sim 1002(1976)$

モルモットの胎生肺の cGMP 依存性タンパクキナ 一ゼのサブュニット構造について研究した。セファデ ックス G-200ゲルろ過法により，この酵素のホ口酵素 が cGMP とヒストンの存在下で触媒ユニット（分子 量 6 万）に解離したが, cAMP 存在下では解離しなか った。ホロ酵素, ヒストンおよび $\mathrm{c}-\mathrm{G}-{ }^{3} \mathrm{H}-\mathrm{GMP}$ を水 冷下で 1 時間保持したのち, セファデックス G-200で ゲルろ過すると, 非遊離状態にある放射能は分子量 3 万に相当する画分に溶出された。この結合 $c-G-{ }^{3} \mathrm{H}-$ GMP は技そらくは酵素の調節サブニニットに結合し ているものと推定された。
（奥田） 


\section{3 リン脂侗小胞のラット HDL への転換}

The in vivo Transformation of Phospholipid Vesicles to a Particle Resembling HDL in the Rat

L. Krupp, A.V. Chobanian, P.I. Brecher: Dept. of Med. and Biochem., Boston Univ. Sch. of Med., Boston, Mass., Biochem. Biophys. Res. Commun., 72, (4) $1251 \sim 58$ (1976)

${ }^{14} \mathrm{C}$ で標識したコレステリルオレン酸あるいはレシ チンを含さリン脂質小胞をラット静脈に注射してから 短時間内に括ける血しょう中の放射能を臭化カリ密度 遠心拈よびセファロース $4 \mathrm{~B}$ B ラムより分画し, 液体 シンチレーションスペクトロメータで測定した。その 結果, それらの放射能は高密度リポタンパクに相当す る画分に存在していた。in vitroで, リン脂質小胞と 血しょうを保持させた場合も上に述べたような変化が 認められた。

(頼)

\section{Adenylate cyclase の脱感作}

Hormone-Dependent Desensitization of VasoPressin-Sensitive Adenylate Cyclase

C. Roy, G. Guillon, S. Jard: Lab. de Physiol. Cel., Col. de France, Paris-France, Biochem. Biophys. Res. Commun., 72, (4) 1265〜70 (1976) ブタ腎臓の膜標品を（8-lysine） vasopressin[I]あ るいはそのアナローグと一定時間以上保持させると I 感受性 adenylate cyclase (II) の脱感作が誘導され た。脱感作には高濃度の ATP を要求し，I の濃度 およびその前処理時間に依存性を示した。Iで 1 時間 前処理するとIによって促進されるII の活性が前処理 しない場合の 50 〜 $\%$ \%であった。脱感受にはある受容 体が関与していると推定された。な拓 II の活性はIの 存在下で $\alpha-{ }^{32} \mathrm{P}-\mathrm{ATP}$ と 5 分間反応させ, cAMP 画 分への ${ }^{32} \mathrm{P}$ の移行を測定することより求めた。（頼）

\section{5 グルタミン酸脱水素酵素の $\mathbf{C y s H}$ 残基}

Identification of a Cysteine Residue of Glutamate Dehydrogenase that Binds $p$-Chloromercuribenzoic Acid

M.P. Cosson, C. Gros, J.C. Talbot: Lab. d'Enzymol. du C.N.R.S., France, Biochem. Biophys. Res. Commun., 72, (4) 1304 10 (1976)

p-chloromercuribenzoic acid で前処理したグルタ ミン酸脱水素酵素の システイン残基を iodo $\left(2^{-14} \mathrm{C}\right)$ acetate で標識し, trypsin 水解したのち, 高圧ろ紙 電気泳動を行い,ペプチド地図を得た。標識されたの はシステイン 319 を含んでいるペプチド303〜329のみ であった。システイン 319 は補酵素の結合部位である $\beta E$ sheet の中に含まれていた。この部位は酵素活性 と直接関係しないが ADP が NADH と競合して結


に対する結合活性が顕著に変化したのでシステイン 319は酵素の立体構造 (配座) の維持に重要であると推 定された。
8166 ピルビン酸脱水素酵素キナーゼ活性化

Evidence for Lipoic Acid Mediated NADH and Acetyl-CoA Stimulation of Liver and Kidney Pyruvate Dehydrogenase Kinase

T.E. Roche, R.L. Cate: Dept. of Biochem. Kansas State Univ., Manhattan, Kansas, Biochem. Biophys. Res. Commun., 72, (4) 1375 83 (1976)

$\gamma-{ }^{32} \mathrm{P}-\mathrm{ATP}$ に由来する放射能の酸不溶画分への取 込み初速度よりウシ肝臓および腎臓のピルビン酸脱水 秦醉素キナーゼ活性（I）を測定した。NADHあるい は dithiothreitol（II）はI を促進した。Iを促進しな い濃度の NADH あるいはII をアセチル CoA と同時 添加すると，Iは促進された。七酸はNADHあるい はアセチル CoA によるIの促進を抑制した。0.025 $\mathrm{m} M$ の遊離 ジヒドロリポアミドはIを促進した。II の存在下で $\mathrm{NAD}^{+}$は I を阻害した。したがって，I の促進はジヒドロリポイルトランスアセチラーゼのリ ポ分子が還元あるいはアセチル化されたためである。

(頼)

\section{7 cAMP 依存性タンパク翼キナーゼの促進}

Artifactual Stimulation of Cyclic AMP-Dependent Protein Kinase Activity by the Heat-Stable Protein Kinase "Inhibitor"

G.G. Rousseau, M.D. Visscher: Univ. de Louvain and Intern. Inst. of Cel. and Mol. Pathol., Brussels, Belgium, Biochem. Biophys. Res. Commun., 72, (4) $1423 \sim 29$ (1976)

ラット肝臓より調製した熱安定性タンパク質キナー ゼ阻害因子 (I) はウシ骨格筋 CAMP 依存性タンパク 質キナーゼ (II) の活性を阻害し, 低濃度の I はII の活 性を促進することが報告されているが，著者らはIに よる II の活性の促進は artifact であることを指摘し た。すなわち，IIはガラス試験管壁に付着されやすい ために，II 活性が過小標価された。この付着はヒス トン,トリプシンあるいはI の添加によって防止され た。したがって，IによるII活性の促進は artifact で あった。な拉，II活性は $\gamma^{-32} \mathrm{P}-\mathrm{ATP}$ に由来する放射 能の酸不溶画分への取込みより求めた。

(頼)

\section{8 酵母の carboxypeptidase Y の生合成}

Biosynthesis of Carboxypeptidase $\mathrm{Y}$ in Yeast. Evidence for a Precursor Form of the Glycoprotein A. Hasilik, W. Tanner: Fachbereich Biol. der Univ. Regensburg, Biochem. Biophys. Res. Commun., 72, (4) 1430 36 (1976)

N-acetyl-L-tyrosine ester を加水分解する活性が 酵母の膜画分に存在した。この活性の半分は carboxypeptidase $\mathrm{Y}$ であった。この液胞酵素の抗体と ${ }^{3} \mathrm{H}$-phe で短時間標識した細胞の膜画分を反忘してえられた放 射性沈殿物を SDS-polyacrylamide gel 電気泳動にか けると，その移動度は標準 carboxypeptidase より小 さかった。短時間標識後非放射性 phe で希釈すること によりこの移動度の小さい物質は carboxypeptidase の先駆体であることがわかった。 
8169 部分脱脂されたバクテリオロドブシン

Bacteriorhodopsin Depleted of Purple Membrane Lipids

M. Happe, P. Overath: Max-Planck-Inst. fur Biol., Tübingen, FRG, Biochem. Biophys. Res. Commun., 72, (4) 1504 11 (1976)

${ }^{32} \mathrm{Pi}$ を含む培地で生育させた Halobacterium halobium 細胞より， ${ }^{32} \mathrm{P}$ で標識された紫膜を分離し， 20 $\mathrm{m} M$ の dodecyl trimethyl ammonium bromide で 可溶化したのち, ショ糖密度勾配遠心あるいはゲルろ 過し, 各画分の放射能および560nmの吸収を測定した 結果, バクテリオロドプシン画分の $90 \%$ 以上のリン脂 質が除去された。この部分脱脂されたバクテリオロド プシンおよびその他の生物から由来した脂質，たとえ ば大豆レシチンあるいは大腸菌の脂質画分より再構成 された膜小胞は, 光反応によるプロトンの取込み活性 を示した。

\section{DCMU 非感受性 Hill 反态関与リン酸化}

Phosphorylation Associated with the DCMUInsensitive Hill Reaction

S. Izawa, S.P. Berg: Dept. of Biol., Wayne State Univ., Detroit, Michigan, Biochem. Biophys. Res. Commun., 72, (4) 1512 18 (1976)

クロロプラストに存在する 3-(3,4-dichlorophenyl) -1,-1-dimethylurea (DCMU) 非感受性, silicomolybdate（I）還元反応成分は光リン酸化活性をもたない と報告されたが，著者らは反応系に I の加水分解を遅 らせる薬剤を添加することによって，光リン酸化が 行われる条件を見だした。すなわち，反応系にIを dimethyl sulfoxide に溶かしてから用いることおよび $5 \%$ glycerol を添加することであり，そのリン酸化 効率 $\left(P / e_{2}\right)$ は0.27であった。なお，光りン酸化活性 は ${ }^{32} \mathrm{Pi}$ の ATP 画分への取込みを求めることにより 測定した。

\section{Ala 能動輸送活性をもつ人工膜小胞}

Preparation of Artificial Vesicles Having an LAlanine Uptake Activity which Requires NADH as Energy Source

K. Hayakawa, T. Ueda, I. Kusaka, S. Fukui: Inst. of Appl. Microbiol, Univ. of Tokyo, Biochem. Biophys. Res. Commun., 72, (4) 1548 53 (1976)

Bacillus subtilis $\mathrm{W}-23$ の細胞膜画分より分離し た疎水性タンパク質および種々の脂質,すなわち，たま ごあるいは大豆りン脂質, あるいは B. subtilis $\mathrm{W}-$ 23 脂質を音波処理して人工膜小胞を形成し, ${ }^{14} \mathrm{C}-\mathrm{Ala}$ と保持させたのち，メンブランフィルターでろ過し， フィルターに残った放射能から膜小胞の Ala 能動輸送 活性(I)を求めた。 NADH あるいは ascorbatephenazine methosulfate をエネルギー源として供給した場 合, 顕著なIが認められた。I は温度に依存し, 呼吸 阻害剤 $(\mathrm{KCN})$ および脱共役剤 (carbonylcyanide $\mathrm{m}^{-}$ chlorophenyl hydrazone) で阻害された。

\section{S-Adenosyl methionine 結合タンパク}

Regulation of Transmethylation by an S-Adenosylmethionine Binding Protein

J.D. Smith: Dept. of Chem., Miami Univ., Oxford, Ohio, Biochem. Biophys. Res. Commun., 73, (1) $7 \sim 12$ (1976)

ラット肝蔵のホモジネートの $100,000 \times \mathrm{g}$ 上澄みを 硫安分画，抽よびゲルろ過によって S-adenosylmethionine (SAM) 結合タンパク質を部分精製した。 NAM 結合活性は ${ }^{3} \mathrm{H}-\mathrm{SAM}$ および肝蔵ホモジネート の各画分を混合させたのちに Sephadex G-25 カラム にかけ，その void volume の放射能から求めた。 SA M結合タンパク質はラット肝臓に叔ける脂質メチル化 醉素系である, phosphatidyl ethanolamine: SAM-Nmethyltransferase および RNA メチル化酵素系で ある, tRNA methylase 複合体の反応速度および反 応生成物の生成量を促進した。

\section{3 ラット肝細胞における bile acid 透過系}

Effect of Albumin on Bile Acid Uptake by Isolated Rat Hepatocytes. Is There a Common Bile Acid Carrier?

M.S. Anwer, R. Kroker, D. Hegner: Inst. fur Pharmakol., Tosikol. und Pharm. Fachbereich Tiermed. der Univ. München, Germany, Biochem. Biophys. Res. Commun., 73, (1) 63 71 (1976)

分離したラット肝細胞に ${ }^{14} \mathrm{C}$-cholic acid (I) ある いは ${ }^{14} \mathrm{C}$-taurocholic acid を保持させたのち, シリ コン油中で遠心し，沈殿し心肝細胞の放射能より，I およびII の取込み活性を調べた。アルブミンは I の取 込みを非拮抗的，II の取込みを拮抗的に阻害した。種 々の胆汁酸は I 拈よび II の取込々を阻害したが，同じ 阻害剂仙よる I お。ひび II の取込み阻害度は相違してい た。以上の結果より，I および II 1 種類以上の担体 によって輸送され，IIはIより良い効率で輸送される と推定した。

\section{4 培暴線維芽細胞のリン脂笛代謝之血清}

Early Effects of Serum on Phospholipid Metabolism in Untransformed and Oncogenic VirusTransformed Cultured Fibroblasts

A. Ciechanover, A. Hershko: Dept. of Clin. Biochem., Technion-Israel Inst. of Technol., Sch. of Med., Haifa, Israel, Biochem. Biophys. Res. Commun., 73, (1) 85〜91 (1976)

血清を含まない培地で培養している線維芽細胞に血 清を添加すると同時に ${ }^{32} \mathrm{Pi}$ を添加し，一定時間後, 脂質を抽出し，TLC で展開したのち各スポトの放射 能を測定した。血清の添加により，ホスファチジルイ ノシトール (I) への放射能の取込みが特異的に著しく 促進された。短時間および長時間の標識によりIの放 射能を比較した結果, 血清はI の全蓄積量汇影響しな かったが，Iの代謝回転速度を促進したことがわかっ た。線維芽細胞に SV-40 ウイルスを感染させると, 血清の添加とは無関係に, ${ }^{32} \mathrm{Pi}$ より I への放射能の取 込みは同じ速度で行われた。 
8175 種々脂肪酸による Guanylate cyclase の促 進

Stimulation of Guanylate Cyclase Activity by Several Fatty Acids

T. Asakawa, I. Scheinbaum, R.J. Ho: Earl W. Sutherland Res. Lab., Dept. of Biochem., Univ. of Miami Sch. of Med., Miami, Florida, Biochem. Biophys. Res. Commun., 73, (1) 141 4 (1976)

ラット脂肪細胞の細胞質膜の guanylate cyclase 活 性は oleic acid (I), linoleic acid (II), あるいはarachidonic acid によって7〜11倍促進された。guanylate cyclase 活性は $\alpha^{-32} \mathrm{P}-\mathrm{GTP}$ を基質として用い, 反応後の cGMP 画分の放射能から求めた。I あるい IIによる酵素活性の促進は酵素タンパク質および添加 脂肪酸の濃度に依存した。 $150 \mu \mathrm{g} / \mathrm{ml}$ タンパク質の細 胞膜に0. $6 \mathrm{~m} M$ の II を添加した場合, 促進効果は最高 （12倍）であり，洗浄によって II を除去すると促進効果 は部分的に打ち消された。そのほか，脳皮質および肝 臓の膜結合性 guanylate cyclase 活性もIIによって促 進された。

\section{6 新合成 DNA およびクロマチン}

Rapid Assembly of Newly Synthesized DNA Replication Intermediates

C.E. Hildebrand, R.A. Walters: Cel. and Mol. Biol. Group, Los Alamos Sci. Lab., Univ. of Calif., Los Alamos, Biochem. Biophys. Res. Commun., 73, (1) $157 \sim 63$ (1976)

チャイニーズハムスター培養細胞の核の新しく複製 をしている DNA を ${ }^{3} \mathrm{H}$-thymidine で均一に標識し たのちMicrococcal ヌクレアーゼで処理し，クロマチ ンのサブニニット構造をショ糖密度勾配遠心法で分析 した結果, DNA の新しく複製が行われている部位近 辺のクロマチンサブニニットは，複製の行われていな い部位より高いヌクレアーゼ感受性を示した。新しく 合成された DNA はただちにクロマチンサブニニッ トを形成することがわかった。

\section{Saccharomyces cerevisiae 液胞 Arg 透 過活性}

Action of Proteinases on the Arginine Transport System of Purified Vacuoles from Saccharomyces cerevisisiae

M. Durr, T. Boller, A. Wiemken: Swiss Federal Inst. of Technol. Zurich, Dept. of Gen. Botany, Zurich, Switzerland, Biochem. Biophys. Res. Commun., 73, (1) 193 99 (1976)

市販タンパク質分解酵素であるテルモリシンおよび 低濃度のプロナーゼは醉母液胞のアルギニン (Arg) 透 過活性(I)を促進したが，高濃度のプロナーゼはI I 阻害した。Argの添加によって阻害作用を示さなくな った。その他のアミノ酸でも保護効果が認められ, 各 アミノ酸の保護効果は Arg 透過系に対する各アミノ 酸の親和性と比例した。テルモリシンおよびプロナー ゼはIを妨げる膜タンパク質を消化することによって Iを促進した。なお，I は ${ }^{3} \mathrm{H}-\mathrm{Arg}$ および液胞を保持 させたのち，ソルビトールおよびショ糖混合液密度勾 配遠心で沈殿した液胞の放射能より求めた。

(頼)
8178 リボソームタンパク中の新メチルアミノ酸

Identification and Characierization of a New Methylated Amino Acid in Ribosomal Protein L33 of Escherichia coli

C.N. Chang, M. Schwartz, F.N. Chang: Dept. Biol., Temple Univ., Philadelphia, Penn., Biochem. Biophys. Res. Commun., 73, (2) 233 39 (1976)

大腸菌Q13のリボソームタンパク L 33の水解物中に 存在する新しいメチル基含有アミノ酸について検討し た。大腸菌Q13，B扎よび MRE600株を ${ }^{14} \mathrm{C}-\mathrm{CH}_{3}-\mathrm{Met}$ 存在下で培養し，L33を分離した。ベックマンPA-28 樹脂カラムクロマトグラフィ，高圧ろ紙電気泳動など

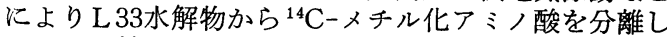
た。Q13株には 2 種のメチル化中性アミノ酸が検出さ れたが，他の 2 株にはこのうちの 1 方だけが検出され $\mathrm{N}$ ーモノメチルアラニンと同定された。本報告でこの アミノ酸がリボソームタンパクに存在することが初め て明らかにされた。

\section{3T6 細胞の DNA 合成と細胞分裂の促進}

Stimulation of DNA Synthesis and Cell Division in a Chemically Defined Medium: Effect of Epidermal Growth Factor, Insulin and Vitamin $B_{12}$ on Resting Cultures of 3T6 Cells

K. Mierzejewski, E. Rozengurt: Tumour Cell Lab., Imperial Cancer Res. Fund., Lincoln's Inn. Fields, London, Biochem. Biophys. Res. Commun., 73, (2) $271 \sim 78$ (1976)

化学的に限定された培地で 3 T6 細胞の DNA 合成 が行われるようになった。まったく血清を含まない培 地にインシュリン，ビタミン $\mathrm{B}_{12}$, 表皮生長因子を加 觉, この培地で ${ }^{3} \mathrm{H}$-メチルチミジンと休止期にある 3 T6 細胞を保温し, 酸不溶画分にとり込まれた放射能 から DNA 合成量を求めた。また, 細胞と ${ }^{3} \mathrm{H}-$ チ ジンを反応させ，固定後オートラジオグラフィにより 標識された核の割合を求めた。その結果, 細胞集団の 80 一 $90 \%$ が DNA 合成を行うようになり, 細胞分裂は表 皮生長因子添加後48～72時間で観察された。（奥田）

\section{DNA からウラシルを遊離する酵素}

A Human Enzyme that Liberates Uracil from DNA

M. Sekiguchi, H. Hayakawa, F. Makino, K. Tanaka, Y. Okada: Dept. Biol., Fac. Sci., Kyushu Univ., Fukuoka, Biochem. Biophys. Res. Commun., 73, (2) 293〜99 (1976)

異常な塩基を含む DNA に作用して，DNA から異 常塩基を除去する醉素 (I) がヒト細胞に存することを

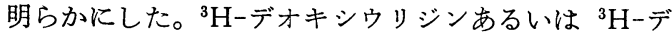
オキシアデノシンを含む培地中でファージ PBS1 を枯 草菌に感染させたのち, ${ }^{3} \mathrm{H}-\mathrm{DNA}$ を抽出，精製した。 また， ${ }^{3} \mathrm{H}$-チミンで大腸菌 DNA を標識した。正常拉 よび色素性乾皮症 (II) 細胞の皮らに由来する線維芽細 胞の超音波抽出液と ${ }^{3} \mathrm{H}-\mathrm{DNA}$ を反応させ，酸可溶性 放射能から I 活性を測定した。その結果，I はウラシ ル含有 DNA に特異的に作用し，正常之II 両細胞に同 レベルの I 活性が検出された。
(奥田) 


\section{RNase Iの基啠特異性}

Specificity of Cleavage by Ribonuclease III

S. Bishayee, U. Maitra: Dept. Develop. Biol. and Cancer, Albert Einstein Col. Med., Yeshiva 73, (2) $306 \sim 13$ (1976)

RNase III (RIII) の基質特異性について検討した。標

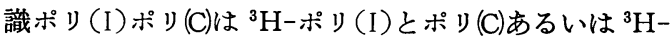
ポリ(C)とポリ (I)を室温で 2 時間反応させて合成した。 ポリ(A)・ポリ(U)は合成 DNA・RNA 混成の場合と同様 にして調製した。精製 RIII と二本鎖の合成ホモポリマ 一 RNA を反応し, 酸不溶性放射能の減少から RIII 活 性を測定した。その結果，RIII はすへての複式ホモポ リマー RNA 構造に作用したが，ポリ(U)・ポリ(A)を基 質にするとポり(A)よりポり(U)を著しく速く切断した。 また，切断されたヌクレオチドの長さはポリ(U)，ポリ (A)でそれぞれ5-8，40-60であった。

(奥田) Univ., Bronx, Biochem. Biophys. Res. Commun.,

8182 ダイズハイ軸のヒストン H1 キナーゼ

Lysine-rich Histon H1 Kinase from Soybean Hypocotyl

P.P.C. Lin, J.L. Key: Dept. Botany and Biochem., Univ. Georgia, Athens, Biochem. Biophys. Res. Commun., 73, (2) 396 403 (1976)

非常にリジンに豊んだヒストンH 1 を特異的にリン 酸化し，かつ，環状ヌクレオチドに依存しないタンパ クキナーゼ (PK) について検討した。黄化大豆の芽生 え, 大豆の熟成ハイ軸をホモジナイズし，PK を部分 精製した。PK， $\gamma^{-32} \mathrm{P}-\mathrm{ATP}$ ，ヒストンなどを反応さ せ, 酸不溶画分の放射能から PK 活性を測定した。そ の結果，PK の分子量は 48,500で， cAMP あるいは cGMP とは結合しなかった。PK 活性には $\mathrm{Mg}^{2+}$ ある いは $\mathrm{Mn}^{2+}$ が必要で, アルギニンに富むヒストン $(\mathrm{H}$ 3, H4) はH1のリン酸化を阻害した。H3やH4は酶素 のH1に対するKmにではなく， $V_{\max }$ に影響を与えた。

（奥田）

\section{3 照射および非照射マイマイガ誘引性}

Relative Attractiveness of Irradiated LaboratoryReared Female Gypsy Moths and Nonirradiated Laboratory-Reared and Feral Females

J.V. Richerson: Dept. of Entomol., Penn. St. Univ., Univ. Park, J. Econom. Entmol., 69, (5) 621 22 (1976)

マイマイガの雌の蛹を線量率5390R/分で線量20000 $\mathrm{R}$ のガンマ線によって不妊化した。マイマイガが群り きて荒された地域打よび荒されていない地域において 行った試験で，非照射の野生のマイマイガの雌は，実 験室で飼育された照射および非照射の雌よりも野生の 雄に対して誘引性が強かった。ガにより荒された地域 では, 非照射の実験室の雌は照射した実験室の雌より 誘引性が強かった。しかし，荒されていない地域で は，この 2 つの実験室の雌の間には差がなかった。

(松岡)

\section{4 蛹に照射したマダラメイガの性競合性}

Sexual Competitiveness of Adult Indian Meal Moths Irradiated as Mature Pupae

M.Y.Y. Ahmed, J. H. Brower, and E.W. Tilton: Stored-Product Insects Res. and Develop. Lab., Agric. Res. Serv. USDA, Savannah, J. Econom. Entmol., 69, (6) 719 21 (1976)

ノシメマダラメイガの蛹に ${ }^{60} \mathrm{Co}$ のガンマ線を50キ ロラド照射した場合，照射雄は未照射雌と交配しても 生殖不能であった。照射雄，未照射雌および雄を 1 : 1：1の比にすると $28.5 \%$ の不受精卵を生じた。照射 雄を未照射雄に対し25：1 まで増加すると，不受精卵 は91. 8\%まで増した。照射雄と雙を未照射雄と雙と 1 : $1: 1: 1,5: 5: 1: 1,10: 10: 1: 1$ およ び15：55：1：1の比で共存させた場合, 不受精卵の 割合は，それぞれ54.1，95.7，81.0拉よび $100 \%$ であ った。照射虫の性競合性は低割合を除いて良く，非照 射虫に打ち勝った。

(松岡)
8185 プロトクロロフィリドホロクロム

Enzymic Nature of the Protein Moiety of Protochlorophyllide Holochrome

Y. Manetas, G.A. Akoyunoglou: Dept. of Biol., Nucl. Res. Center "Demokritos". Athens, Greece, Plant Physiol., 58, (1) 43〜46 (1976)

黄化オオムギとインゲンの葉を暗所で $3 \mathrm{~m} M 4-\delta-$

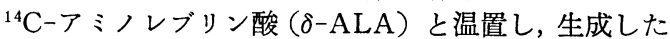

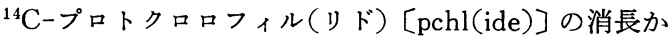
ら pchl(ide) タンパクの特性を調べた。pchl(ide)の 濃度と比放射能は温置時間とともに増加した。また温 置過程で短時間照明して生成した chl. および処理葉 から抽出したホロクロム結合 pchl(ide) は ${ }^{14} \mathrm{C}$-標識さ れ，その比放射能は全 pchl(ide) の比放射能と同じで あった。以上の結果, ホロクロムタンパク (HCP)の 活性サイトで内生 pchl(ide) と $\delta$-ALA 誘導 pchl (ide) 間で交換があること， HCP が酵素として作用 することが示された。
(武長)

\section{6 土壤，泥炭における表面活性刜の分解}

Degradation of Nonionic Surfactant in Soils and Peat

N. Valoras, J. Letey, J.P. Martin, J. Osborn: Dept. of Soil Sci. and Agric. Eng., Univ. of Calif., Riverside, Soil Sci. Soc. Amer. J., 40, (1) 60 63 (1976)

土褰および泥炭に ${ }^{14} \mathrm{C}$ 標識非イオン系土壌表面活性 剤3685を 0〜30,000ppm 添加，インキュベートして分 解を調べた。分解率の経時的変化は S 字曲線を描き, 添加濃度の増加に伴って分解の遅延期間は増加した。 一般に表面活性剂に対する吸着性の低い土堹で最高の 分解速度, 分解率が示された。また土壤水分量の減少 によって分解速度は減少し，好適分解条件下で 1 年間 に添加 ${ }^{14} \mathrm{C}$ の約 75 85\% が ${ }^{14} \mathrm{CO}_{2}$ として放出され た。土壤有機物の分解は，表面活性斉約10,000 ppm以 下の施用では影響されなかったが，それ以上の高濃度 施用で漸次減少した。 (武長) 
8187 乾式燃焼法による土壤中 ${ }^{14} \mathrm{C}$ 殺虫剤の測定

Determination of ${ }^{14} \mathrm{C}$-Labeled Pesticides in Soils by a Dry Combustion Technique

H.H. Cheng, F.O. Farrow: Dept. of Agronomy and Soils, Washington State Univ., Pullman, Soil Sci. Soc. Amer. J., 40, (1) 148 50 (1976)

Leco 高温誘導炉による土壤全炭素の酸化, 測定法 を改良し，土猿中 ${ }^{14} \mathrm{C}$ 標識殺虫剤の乾式酸化燃焼法と 全 ${ }^{14} \mathrm{C}$ 測定法を研究した。carboxyl- ${ }^{14} \mathrm{C}$-picloram(I), carboxyl-14 $\mathrm{C}-2,4-\mathrm{D}(\mathrm{II})$, benzothiazolyl-2-14 $\mathrm{C}-\mathrm{met}$ habenzthiazuron(II) 各 $1 \mathrm{ppm}\left(\left(0.01 \mu \mathrm{Ci}^{14} \mathrm{C}\right)\right.$ を含む 土壤 $0.5 \mathrm{~g}$ を $900^{\circ} \mathrm{C}, 2$ 時間燃焼し, 発生した $\mathrm{CO}_{2}$ を $0.5 \mathrm{~N} \mathrm{NaOH} 50 \mathrm{ml}$ に捕集し, ${ }^{14} \mathrm{C}$ は液シン, 全 Cは 滴定法で測定した。全 ${ }^{14} \mathrm{C}$ 回収率は (I) $93-103 \%$,(II) 93-102\%，(III) 95-99\%，平均 $97 \%$ であった。また 6 か月間(III) を温置した土壤についてアセトン抽出を行 った結果, 抽出物と残さ中の ${ }^{14} \mathrm{C} の$ 合計值は温置土壤 中全 ${ }^{14} \mathrm{C}$ 量に匹敵した。

(武長)

\section{$8188{ }^{14} \mathrm{C}$ 標識 Ferulic acid の分解}

Decomposition of Specifically Carbon-14-labeled Ferulic Acid: Free and Linked into Model Humic Acid-type Polymers

J.P. Martin, K. Haider: Dept. of Soil Sci. and Agric. Eng., Univ. of Calif., Riverside, Soil Sci. Soc. Amer. J., 40, (3) 377 80 (1976)

$1^{-{ }^{14} \mathrm{C}-}, 2^{-14} \mathrm{C}-, 33^{-14} \mathrm{C}-, \mathrm{O}^{14} \mathrm{CH}_{3}-$, 環 ${ }^{14} \mathrm{C}-$ ferulic acidを打の打の合成し，土壤と温置した結果，12週 間に $44 \sim 78 \%$ が ${ }^{14} \mathrm{CO}_{2}$ となった。 $1-, 2-2^{14} \mathrm{C}$-酢酸, $1-, 2-, 3{ }^{-14} \mathrm{C}-$ ピルビン酸, ${ }^{14} \mathrm{COOH}$ vanillic, protocatechuic acid からの ${ }^{14} \mathrm{CO}_{2}$ 損失は平均 $84 \%$ であっ た。hydroxyphenol と tolueneから腐植酸ポリマーに 連鎖した場合の ${ }^{14} \mathrm{C}$ 損失は $7 \sim 25 \%$, hydroxybenzoic acid では環・側鎖 ${ }^{14} \mathrm{C}$ の $3-7 \%, \mathrm{O}^{14} \mathrm{CH}_{3}$ の約 $21 \%$ が失われた。また ${ }^{14} \mathrm{C}$-ferulic, vanillic acid を $S$. chartarum または H. toruloidea の培地に加えたと き，環 ${ }^{14} \mathrm{C}$ の11〜52\%が，また veratric acid の環 ${ }^{14} \mathrm{C}$ の 3 〜 \%がそれぞれ腐植酸ポリマーに取り込まれ た。

(武長)

$8189{ }^{74} \mathrm{As}$ の土壤中の形態別分布とガス放出

Chemical Distribution and Gaseous Evolution of Arsenic-74 Added to Soils as DSNA $-{ }^{74}$ As

M.B. Akins, R.J. Lewis: Dept. of Plant \& Soil Sci., Univ. of Tenn. Agric. Exp. Stn., Knoxville, Soil Sci. Soc. Amer. J., 40, (5) 655 58 (1976)

水分, 有機物含量の異なる土塆に ${ }^{74} \mathrm{As}$ 標識 disodium methanearsonate (DSNA- ${ }^{74} \mathrm{As}$ ) $100 \mu \mathrm{g} / \mathrm{g}$ を添加, 温置して ${ }^{74} \mathrm{As}$ ガス放出を調べた結果, 有機物添加括 よび湿潤条件下で ${ }^{74} \mathrm{As}$ ガスの放出は最大であった。 また $\mathrm{pH} 4,6,8$ に調整した数種の土壌に DSNA $-{ }^{74} \mathrm{As}$ を 吸収させたのち， ${ }^{74} \mathrm{As}$ の分画を行った。Fe-As 画分 (0.1 N NaOH 可溶) は平均 $44 \%$ で最も多く，ついで Al-As（0.5N NH $\mathrm{NH}_{4} \mathrm{~F}$ 可溶）が約 $27 \%$ であった。一般 に Al-As 画分は $\mathrm{pH} 4 て ゙, \mathrm{Ca}-\mathrm{As}$ 画分 $\left(0.5 \mathrm{~N} \mathrm{H}_{2} \mathrm{SO}_{4}\right.$ 可溶）は $\mathrm{pH}$ 6.8でそれぞれ分布率は大であった。水 可溶態 (1 $\mathrm{N} \mathrm{NH}_{4} \mathrm{Cl}$ 抽出画分) 之非抽出画分は相互 に逆比例の関係を示した。
$8190{ }^{14} \mathrm{C}$ 標識2,4-Dおよび Chlorpropham の分解

Decomposition of Fungal Mycelia and Humic-type Polymers Containing Carbon-14 from Ring and Side-chain Labeled 2, 4-D and Chlorpropham

D.C. Wolf, J.P. Martin: Dept. of Soil Sci. \& Agr. Eng., Univ. of Calif., Riverside, Soil Sci. Soc. Amer. J., 40, (5) 700 04 (1976)

環または側鎖 $2^{-14} \mathrm{C}$ 標識 2, 4-D あるいは chlorpropham 10ppm 含有培地で Hendersonula toruloidea, Stachybotrys atra を培養した。環 ${ }^{14} \mathrm{C}-2,4-\mathrm{D}$ の放 射能の約 $12 \%$ 腐植ポリマー，4〜6\%が菌系体に存 在し, 環および $2{ }^{-14} \mathrm{C}$ chlorpropham では菌系体約35 $\%$ ，腐植ポリマー3〜24\%が取り込まれた。また $H$. toruloidea, S. atra の環 ${ }^{14} \mathrm{C}-2,4-\mathrm{D}$ からの ${ }^{14} \mathrm{C}$ 部の 分解率は菌系体，腐植ポリマーでそれぞれ $15 ， 35 \%$ 拉 よび13，35\%であった。一方， $2-{ }^{14} \mathrm{C}-2,4-\mathrm{D}$ では環標 識の 2 倍以上の速度で ${ }^{14} \mathrm{CO}_{2}$ に分解された。環 ${ }^{14} \mathrm{C}$ chlorpropham についても菌系体, 腐植ポリマーの ${ }^{14} \mathrm{C}$ は $2-{ }^{14} \mathrm{C}$ 標識よりも分解しにくかった。（武長）
8191 カイコの幼虫脱皮によもなう体壁および中腸 のタンパク質合成能の変動

永田昌男 : 東京大学農学部・東京都文京区弥生, 日 蚕雑, 45，(4）328～36 (1976)

4 令起蚕から 5 令 2 日目までの各時期に ${ }^{14} \mathrm{C}$-ロイシ ン $(0.5 \mu \mathrm{Ci} / \mathrm{g}$ 生体重) を注射し， 4 時間後に解剖し， 体壁预よび中腸のタンパク質への放射能のとりこみを 調ベた。タンパク質の比放射能とアミノ酸プールの比 放射能との比を求め, タンパク質合成能の尺度とし た。その結果, 体壁, 中腸および幼虫体のタンパク質 合成能は食桑期に高く，眠期に低いといら変動をする が，眠期においてもタンパク質合成は行われており， それはまた眠の段階により異なっていることが明らか にされた。

(松岡)
8192 ツマグロヨコバイにおける置換フェニルメチ ルカーバメートの吸収と代謝

守谷茂雄・前田洋一：農林省九州農業試験場，応動 昆誌，20，(4）198～202（1976）

${ }^{14} \mathrm{C}-\mathrm{BPMC}$ 抢よび ${ }^{14} \mathrm{C}-\mathrm{MIPC}$ を合成し，カーバメ 一ト系殺虫剂に感受性の異なる筑後系, 新和系のッマ グロヨコバイに局所施用し，その吸収，代謝を調べ た。虫体表からの薬剤の吸収浸透は速やかで，フェニ ルカーバメート殺虫剤の速効性の一因と考えられた。 殺虫成分の体内への浸透量は筑後系, 新和系の間で差 がないが，水溶性画分，不溶性部中の ${ }^{14} \mathrm{C}$ 放射能はい ずれも筑後系に怙いて高いことが認められ，筑後系と 新和系では体内にお沙る薬剤の消長に差のある可能性 が示唆された。 


\section{3 塩酸エプラジノンの生体内通命（I）}

Metabolic Fate of Eprazinone Hydrochloride. I. Absorption, Distribution, and Excretion of Eprazinone Hydrochloride in vivo

S. Takahashi, et al.: Res. Lab., Chugai Pharm. Co., Ltd., Tokyo, 薬学雑誌, 95, (8) 1002 9(1975)

${ }^{3} \mathrm{H}$-eprazinone-HCl[1-(2-ethoxy-2-phenylethyl) -4-(2-methyl-2-benzoylpropyl-piperazine dihydrochloride, 鎮咳薬】をマウスに po 投与 $(5 \mathrm{mg})$ したと き，全身オートラジオグラムは15分後に高い放射能を 示し，12時間後には大腸，胆の5に強い放射能が認め られた。ラットおよび家鬼に po 投与したときの血中 放射能は 2 時間で最大となり, 家鬼では 1 時間で最高 となった。また，iv 投与の場合の血中濃度はラット， 家鬼とすに 24 時間でほぼ消失した。さらに非放射性 eprazinone をラットおよびヒトに経口投与した場合 の生体内消長についても比色定量法で検討した。

（藤原）

\section{$8194{ }^{60} \mathrm{Co} \gamma$ 綵照射による大麻程子発充阻害}

Studies on Cannabis III. Young Plants from the Seed Irradiated with ${ }^{60} \mathrm{Co} \gamma$ Rays for Inhibiting Their Development after Seedling

H. Shimomura, E. Kuriyama, A. Tomizawa: Tokyo, Col. Pharmacy, Ueno, Tokyo, 蒋学雑誌, 96, (1) $75 \sim 81$ (1976)

栃木県鹿沼産大麻 “南押原 1 号” 種子飞 ${ }^{80} \mathrm{Co} \gamma$ 線照 射を行い，照射線量を異にした処理種子から生長した 幼植物の形態を無処理種子からのそれと比較し，発育 抑制の目的に要する照射線量を考察した。1500，1000 $\mathrm{krad}$ 照射：生育第 1 期で枯死し，発芽しない。500, $200,50 \mathrm{krad}$ 照射：いずれる生育第 3 期の形態で播種 後 $2-3$ 週間で枯死。 $30 \mathrm{krad}$ 照射: 生育第 4 期, 第 5 期の形態で枯死。 $15,5 \mathrm{krad}$ 照射 : 開花期に至るま で枯死することなく非照射区とほぼ同様であった。し たがって実用上 $30 \sim 50 \mathrm{krad}$ の照射が望ましいと思わ れる。

\section{5 抗炎症薬 Y-8004 の铇物䅱差}

Studies on Anti-inflammatory Agents. XXXII. Absorption, Excretion, Distribution and Metabolism of 2-(5H-[1] Benzopyrano [2,3-6] pyridin-7-yl.) propionic Acid (Y-8004) in Rats and Mice

Y. Kato, N. Arima, H. Nishimine: Res. Lab., Yoshitomi Pharm. Ind., Ltd., Yoshitomi-cho, Fukuoka, 薬学雑誌, 96, (7) 819〜26 (1976)

抗炎症薬Y-8004 の雄ラット，マウスでの急性毒性 $\left(\mathrm{LD}_{50}\right)$ 值はおのおの $83.7 \mathrm{mg} / \mathrm{kg}$ および $447.3 \mathrm{mg} / \mathrm{kg}$ （po）で，本種差を解明するため ${ }^{14} \mathrm{C}-\mathrm{Y}-8004$ をラッ 卜，マゥゥス po 投与し，血中 ${ }^{14} \mathrm{C}$ 濃度および生体内 分布を検討したが種差は認められなかった。一方， 72 時間尿，糞中排泄率はラットでおのおの約 $50 \%$ ，約 40 \%, マウスで約 $80 \%$ ，約 20 であった。ラット尿，胆汁 中の主代謝物はY-8004 の acylglucuronide であり, マウスの主代謝物は acylglucoside と推定され，両種 に颃いての抱合様式の差異が認められた。

（藤原）

\section{6 紧獏障害ラットでの菜物の生体内運命}

Metabolic Fate of Drugs in Rats with Experimental Renal Damage

Y. Ishizuka, T. Ariyoshi: Fac. of Pharm. Sci., Nagasaki Univ.: Nagasaki-shi, 薬学雑誌, 96, (9) 1049 56 (1976)

塩化第二水銀 $(\mathrm{Hg} 2.0 \mathrm{mg} / \mathrm{kg}) 1$ 回 $\mathrm{sc}$ 投与72時間 後の腎蔵障害ラットにおける 5,5-diphenylhydantoin $\left({ }^{14} \mathrm{C}-\mathrm{DPH}\right)$ および 2-guanidinomethyl-1-monoazacyloöctane sulfate $\left({ }^{14} \mathrm{C}-\mathrm{EGYT}-739\right)$ の血中濃度, 組織内分布，排泄㧍よび肝の薬物代謝酵素活性につい て検討した。対照群には生理食塩水 $2 \mathrm{ml} / \mathrm{kg}$ 投与した。 ${ }^{14} \mathrm{C}-\mathrm{DPH}$ の血中からの消失は著しい遅延が認められ


った。障害部位の腎組織から放射性物質の消失は遅延 し，胆汁への排泄は増加の傾向にあった。一方，塩化 第二水銀による肝障害は弱かった。（藤原）

\section{7 大麻中の ${ }^{32} \mathbf{P}$ の定量}

Determination of Phosphorus in Cannabis by Neutron Activation Analysis-Measurement of ${ }^{32} \mathrm{P}$ Cerenkov Radiation by Liquid Scintillation Spectrometer-

M. Shinogi, I. Mori: Kobe Women's Col. of Pharmacy, Kobe., 薬学雑誌, 96, (11) 1282 87 (1976)

${ }^{32} \mathrm{P}$ の $\beta$ 線測定に液体 シンチレーションスペクトロ メーターを用いるチェレンコフ光測定を応用し, 大麻 中のリンの定量を行った。その結果，大麻の上部およ び中部の葉と雄花のリン含有量はそれぞれ0.31，0.55 および $0.71 \%$ \%あり，また，これらの值はモリブデン 青法による測定值とよく一致した。なお，本法による リン検出限界は $2.5 \times 10^{-8} \mathrm{~g}$ であった。さらに, リン の化学的分離法および ${ }^{32} \mathrm{P}$ のチェレンコフ光測定条件 についても種々検討した。

（藤原）

\section{8 同位体による薬物代謝の研究}

Studies on Drug Metabolism by Use of Isotopes. XVII. Ion Cluster Technique for Determination of Urinary Metabolites of Butyryl-4-cinnamylpiperazine

S. Baba, S. Morisita, Y. Nagatsu: Tokyo Col. of Pharmacy and Kyorin Chem. Lab., Hachiojishi, Tokyo, 薬学雑誌, 96, (11) 1293 97 (1976)

1-butyryl-4-cinnamylpiperazine (I) 塩酸塩と 1butyryl-4-(cinnamyl-arom. $\left.-\mathrm{d}_{5}\right)$ piperazine $\left(\mathrm{I}-\mathrm{d}_{5}\right)$ 塩 酸塩の等量混合物をマウス，モルモットに皮下投与 (100 mg/kg) し，種々の未知代謝物についてイオン クラスター法で検索した。その結果, 1-butyryl-4-(3methoxy-4-hydroxycinnamyl) piperazine, 1-(3hydroxybutyryl) または (4-hydroxybutryl)-4cinnamylpiperazineおよび 1-(3-hydroxybutyryl) ま たは (4-hydroxybutryl)-4-(4-hydroxycinnamyl) piperazine を検出した。そのさい, 代謝物の存在画分 を確認するため $\mathrm{I}^{-14} \mathrm{C}$ 塩酸塩の代謝実験を同時に行っ た。 （藤原） 
$7118[0: F]$ Potential Errors in the Radioassay of ${ }^{125}$ I, D. Hunter, et al.: Nucl. Med. Dept., Bowman Gray Sch. of Med., Winston-Salem, $J$. Nucl. Med., 16, (10) 952〜54 (1975)

縦孔打よび横孔式のウェル・カウンタで ${ }^{126} \mathrm{I}$ 試料を 計測する場合の計数率特性を調べた。多チャネル波高 分析器を用い, ウェル内の位置によるスペクトルを測 定したところ, 波高值は数 $\mathrm{cm}$ の範用でカウントは変 わらないが, 縦孔ウェルでは sum ピーク值は試料の 位置により非常に変化した。横孔ウェルでは sum ピ ーク值は $2 \mathrm{~cm}$ 範囲で平坦であった。（119108）
7119 [0:G] Quality Control and Testing of ${ }^{99 m}$ Tc-Macroaggregated Albumin, L. Darte, et al.: Dept. Radiat. Phys. and Hosp. Pharm., Univ. of Lund, Nucl. Med., 15, (2) 80 85 (1976)

ゲルクロマト法により市販の ${ }^{99 m} \mathrm{Tc}$ 標識粗大凝集ア ルブミンの品質を検查した。収率97〜99\%，少なくと も $5 \sim 6$ 時間安定, 粒子の約 $80 \%$ が $10 \sim 80 \mu \mathrm{m}$ の径で あった。また $1 \mathrm{mg}$ あたりの粒子数は, $0.4 \times 10^{6}$ と推 定された。肺に拈ける生物学的半減期はヒトで $1 〜 2$

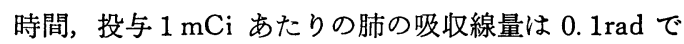
あり，注射後25分間で，肝，脾，または腎への集積は $1 \%$ 以下であった。

(123817)
$7120[0: G]{ }^{125}$ I-Labeling of Fibrinogen by the Chloramine-T Method without Protein Denaturation, J.L. Lazewatsky, et al.: Dept. Nucl. Engs., Mass. Inst. of Technol., Cambridge, Thromb. Res., 8, (3) 373 81 (1976)

精製ウシフィブリノーゲンをクロラミンTを用い ${ }^{125} \mathrm{I}$ で標識し, 凝固性とアガロースゲルろ過でその分 解度を調べた。凝固性タンパクの平均は $92.5 \%$ であり $\mathrm{ICl}$ と酵素法で作った ${ }^{125} \mathrm{I}$-フィブリノーゲンと比較し ても，クロマト上正常であった。子牛に投与した場合 主成分の半減時間は5.1士0.4日であった。

(122217)
7121 [1, 4: A] Abnormal Radionuclide Angiogram in Cervical Lymphadenitis: Case Report, J.S. Stevens, et al.: Charles R. Drew Postgraduate and Martin Luther King, Jr. Gen. Hosp., Los Angeles, J. Nucl. Med., 17, (1) 26 (1976)

頸部リンパ腺炎では同側の鎖骨下動脈系の血流が増 加する。症例 126 藏女性。頭痛のため脳スキャン施行, ${ }^{99 m} \mathrm{Tc}$-パーテクネテート $25 \mathrm{mC}$ i静注し, 前大脳動脈の 動静脈相を 4 秒撮像した。左頸動脈領域全体に放射能 の増加があり, 脳スキャンは正常。左虫歯から左頸り ンパ腺炎を起こしていたものである。27歳女性, 甲状 腺炎を疑われてスキャン施行。 ${ }^{99 m} \mathrm{~T} c$-パーテクネテー 卜 $3 \mathrm{mCi}$ 静注, 右頸動脈全域に放射能の增加あり, 右 頸部深くに軟い大きなリンパ節あり。これは十日間で 消失した。リンパ腺炎はウイルス感染によるものと考 えられた。甲状腺像は正常であった。（120580）

7123 [2:A] Experience in Parathyroid Scanning, L.B. Arkles: Dept. Nucl. Med., Repatriation Gen. Hosp., Heiderberg, Melbourne, Am. J. Roentgenol. Radium Ther. Nucl. Med., 125, (3) $634 \sim 39$ (1975)

42 例の副甲状腺腺腫の疑われる患者に, ${ }^{75} \mathrm{Se}$ の dual peak, ${ }^{131} \mathrm{I},{ }^{99 m} \mathrm{Tc}$ の組合わせの subtraction 法 で，副甲状腺のシンチグラフィを行った。腺腫の検出 率は ${ }^{75} \mathrm{Se}$ dual peak 法では $27 \%$ と悪いが, ${ }^{99 m} \mathrm{Tc}$ ${ }^{131} \mathrm{I}$ subtraction 法では66\%であり, 径 $1.5 \mathrm{~cm}$ 以上の 腺腫は描出可能であった。 ${ }^{99 m} \mathrm{~T} c$ が副甲状腺腺腫に集 積する機構は不明であり,この方法はさらに検討を重 ねる必要がある。

(120713) 
7124 [2: E] Serum Thyrotrophin Concentration: An Unreliable Test for Detection of Early Hypothyroidism after Thyroidectomy, G. Hennemann, et al.: Dept. Int. Med. II, Clin. Endocrinol., Med. Facul. Erasmus Univ. Netherland, Brit. Med. J., 4, (5989) 129 30 (1975)

バセドウ病，中毒性多結節性甲状腺腫，正常機能性 多結節甲状腺腫で12～15年前に亜甲状腺切除術をうけ た患者に扮いて，血中 $T_{4}$ 値は正常域にあるが，血中 TSH 值が正常域か, やや高值を示す 2 群に分けられ た。血中 $T_{3}$ 值は全例において, やや高值を示したが, $\mathrm{TSH}$ 值の正常群と軽度上昇群の $\mathrm{T}_{3}$ 值はおおむね同 様であった。甲状腺切除後, 血清 TSH 值の軽度上昇 は甲状腺機能低下症の存在を示するのである。

(120601)
7125 [2: E] Measurement of Thyroid-Stimulating Hormone in Dried Blood Spot, M. Irie, et al.: 1st Dept. Med., Toho Univ. Sch. Med., Tokyo, Lancet, 2, (7947) 1233 34 (1975)

ろ紙上にスポット状に乾燥させた全血 $20 \mu l$ を用い， その血清 TSH 值を二抗体法による radioimmunoassay により，新生児の代謝異常児発見のスクリー二 ングとして測定した。本法による血清 TSH 值の測定 限界は $5 \sim 10 \mu \mathrm{U} / \mathrm{ml}$ であり，通常の方法による血清 TSH の測定値とよく相関した。本法により 4 歳少女 の原発性甲状腺機能低下症を発見した。本法は方法が 簡便であり，鋭敏であることから，先天性の甲状腺機 能低下症発見のスクリーニングとして，有用と考えら れた。

(120722)
7126 [2: $\mathrm{E}$ ] $\mathbf{T}_{\mathbf{3}}$ Release from Thyroid Slices as an Assay for Thyroid Stimulators, P. Laurberg, et al.: 2nd Univ. Clin. of Int. Med., Kommunehospitalet, Arahus, Denmark, Scand. J. Clin. Lab. Invest., 35, 723〜27 (1975)

甲状腺スライスのインキュベーションによる $\mathrm{T}_{3}$ の 遊出に扣よぼす甲状腺刺激物質の影響を検索した。甲 状腺スライスはプールしたブタ甲状腺を用い, 甲状腺 刺激物質としてヒト TSH, ウシ TSH, バセドウ病血 清を用いた。最高の感度を得るとして，16時間のイン キューベーションを行った。ウシ $\mathrm{TSH}$, ヒト TSH, バセドウ病血清により log-log スケールで直線的な容 量反応曲線を得た。ウシ TSH では $5-125 \mu \mathrm{U} / \mathrm{ml}$ の 濃度で直約関係が得られ, ウシ TSH とバセドウ病血 清では平行な希釈曲線が得られ，ヒトTSHによる希 釈曲線はかなり急勾配であった。

(121775)
$7127[2,6: \mathrm{E}] \quad \mathbf{T}_{3}$ Resin Uptake in ProteinCalorie Malnutrition, Y. Ingenbleek, et al.: Inst. Clin. Nutr. Infant., Univ. Dakar, Senegal, West Africa, Acta Endocrinol., 81, (2) 283 87 (1976)

${ }^{131} \mathrm{I}-\mathrm{T}_{3}$-resin 摂取率が kwashiorkor の急性期に上 昇し，摂取をはじめて 2 週後には正常值に復帰した。 ${ }^{131} \mathrm{I}-\mathrm{T}_{3}-$ resin 摂取率は TBG $の \mathrm{~T}_{4}$ 結合能に逆比例す るが,この逆相関は入院時に最高となり $(r=-0.88)$, 臨床症状の回復により，健常人の相関 $(r=-0.63)$ に 復㷌した。これらの成績は ${ }^{131} \mathrm{I}-\mathrm{T}_{3}$-resin 摄取率に $\mathrm{TBG}$ の $\mathrm{T}_{4}$ 結合能に大きく関与していることを示す ものである。

(121363)
7128 [4: A] Radionuclide Imaging of the Myocardium in the Resting and Hyperemic States, D.L. Williams, et al.: Nucl. Med./Cardiol. Res. Group at Seattle VA Hosp., Appl. Radiol. Nucl. Med., 5, (1) 161 66 (1976)

安静時と運動時における必筋の RI イメージに関す る総説。用いられる RI すなわち ${ }^{98 m} \mathrm{Tc}$ あるいは ${ }^{113 m} \mathrm{In}$ 標識 MAA あるいはアルブミンミクロスフェアにつ いて,イメージ技術, イメージ検查の安全性, 正常な る安静時イメージ像, 異常なる安静時イメージ,スト レス時における灌流欠損, さらにイメージの収集およ び処理について論じている。

(121510)
7129 [4 : A] Detection of Unstable Angina by ${ }^{\text {99m }}$ Tc-Pyrophosphate Myocardial Scintigraphy, A.M. Abdulla, et al.: Dept. Radiol. and Nucl. Med., Mount Carmel Mercy Hosp., Detroit., Chest, 69, (2) $168 \sim 73$ (1976)

心筋梗塞部位に集積する ${ }^{99 m} \mathrm{Tc}$-pyrophosphate ( ${ }^{99 m}$ Tc-PYP) が高度な虚血部位ではあるが壊死をお こしていない心筋にとりこまれるか否かを17人の患者 において調べた。らち 7 人の患者は心電図および検査 所見に拈いて不安定な狭心症の診断基準をみたしてい た。しかしながら心電図あるいは酵素学的には心筋梗 塞の所見は呈していなかった。これら 7 人のらち 5 人 は異常な局在性のイメージパターンを呈したが 1 例は ぞちらともいえない像を呈した。安定した狭心症の 10 人のコントロールグループではすべて心筋シンチグラ ムは正常であった。 
7130 [4: A] Detection of Myocardial Damage with ${ }^{99 m}$ Tc-Pyrophosphate after Open Heart Surgery, I. Lowenthal, et al.: VA Hosp., West Roxburry, Boston, Clin. Res., 23, (5) 567A (1975)

開胸外科手術を施行した患者において急性心筋梗塞 の有無を ${ }^{99 m} \mathrm{Tc}$-pyrophosphate (PYP) による心筋シ ンチによって検討した。ECG, VCG および CPK な ども同時に測定した。30例中 2 例において術後陽性像 を呈し, ECG, VCG および醅素も急性心筋梗塞の像 を呈した。第 3 番目の症例は弱い陽性像を示し CPKMB が上昇したが ECG, VCG には変化はなかった。 6 例の陰性像を呈した患者に打いては CPK-MB は存 在したが ECG，VCG では診断的変化はなかった。 ${ }^{99 m}$ Tc-PYP 心筋シンチは開胸心蔵手術後の心筋障害 の補助的診断に有用である。

(120223)
7131 [4:A] ${ }^{99 m}$ Tc-Stannous Pyrophophosphate Myocardial Scintigrams to Recognise Acute Subendocardial Myocardial Infarcts in Patients, L. Poliner, et al.: Dept. Med., Univ. Texas Health Sci. Center, Dallas, Clin. Res., 24, (1) 42 A (1976) 急性の心内膜下梗塞 (SEMI) は心電図のみでは診 断がむずかしい。著者らは ${ }^{99 m} \mathrm{Tc}$-pyrophosphate ( $\left.{ }^{99 m} \mathrm{~T} c-\mathrm{PYP}\right)$ を胸痛を有するが貫通性心筋梗塞を心 電図上は呈していない179名の患者に拈いて SEMI を 診断するために抗こなった 51 名の患者において ${ }^{99 m} \mathrm{~T} c-\mathrm{PYP}$ シンチは陽性像を呈した。44名は血清酵 素が上昇し SEMI に相当する変化を呈した。7人の 患者は陽性シンチを示しかつ ST.T 波は SEMI に相 当したが血清学酵素值は正常であった。SEMIの患者 においては ${ }^{99 m} \mathrm{Tc}-\mathrm{PYP}$ シンチは診断上有用と思われ る。

(121038)
$7132[4: A]$ Comparison of ${ }^{81} \mathbf{R b}$ and ${ }^{99 m} \mathbf{T c}-$ Pyrophosphate Sensitivity in the Diagnosis of Exercise Induced Ischemia-Usefulness of ${ }^{99 \mathrm{~m}} \mathrm{Tc}$ Pyrophosphate in the Acute Myocardial Infarction, D.S. Berman, et al.: U.C., Davis, Clin. Res., 24, (2) 80A (1976)

15名の虚血性心疾患患者に安静時と運動時に ${ }^{99 m} \mathrm{~T}$ cpyrophosphate (PYP) シンチグラムを施行した。ま たそのらちの11名には ${ }^{81} \mathrm{Rb}$ のシンチグラムを施行し た。その結果一過性の心筋虚血は PYP シンチグラム では陽性像を示さないことがわかった。すなわち運動 負荷時の PYP シンチグラムは ${ }^{81} \mathrm{Rb}$ シンチグラムと 異なり冠状動脈の虚血性疾患のスクリーンニングには 用いられないことが判明した。しかしながら PYP 陽 性シンチグラムといらものは急性の心筋壊死に対して 特異的であるといらことも判明した。

(121842)
7133 [4: A] Lack of Specificity of ${ }^{99 m}$ Tc-Polyphosphate Scans for Acute Myocardial Infarction, E.W. Gertz, et al.: VA Hosp., Univ. of Calif., San Francisco, Clin. Res., 24, (2) 83A (1976)

427 名の骨シンチグラムを施行し，かつ心電図を記 録してある患者について心筋への ${ }^{99 m} \mathrm{Tc}$-pyrophosphate の蓄積を検討した。結果としてシンチグラムが 陰性であったものについてみると269例が心電図正常, 19例が心電図異常であった。シンチグラム陽性像であ った者についてみると35例が心電図正常, 104 例が心 電図異常であった。

(121843)
7134 [4: A] The Specificity of the Diffuse Pattern of Cardiac Uptake in Myocardial Infarction Imaging with ${ }^{99 m}$ Tc-Pyrophosphate, $\mathrm{M}$. Taradash, et al.: Univ. Calif., San Franciseo, Clin. Res., 24, (2) 89A (1976)

${ }^{99 m}$ Tc-pyrophosphate (PYP) の心笳への取込みに ついて検討を加えた。結論として(1)び漫性の PYP の 心筋への取込みは心内膜下梗塞が厳密な酵素学的診断 基準によって定義される場合には心内膜下梗塞に特異 的とはいえないということ，(2) PYP クリアランスの 遅延あるいは組織への集積低下がび漫性の心筋イメー ジ陽性像を形成すること。すなわち心プールによって 陽性像がみられる場合があるということが判明した。
7135 [4: A] Measurement of Acute Myocardial Infarcts in Dogs with ${ }^{99 m}$ Tc-Stannous Pyrophosphate Scintigrams, E.M. Stokely et al.: Parkland Mem. Hosp. and Univ. Texas Health Sci. Center, Dallas, J. Nucl. Med., 17, (1) 1 5 (1976) ${ }^{99 m} \mathrm{Tc}$-pyrophosphate ( $\left.{ }^{99 m} \mathrm{Tc}-\mathrm{PYP}\right)$ をイヌの実験 的心筋梗塞の診断に用いて梗塞部位を測定した。 ${ }^{99 m}$ Tc-PYP シンチグラムは左前冠動脈結禁後 24 ない し32時間後に施行した。すべてのイヌに拉いてシンチ グラムは陽性像を示した。シンチグラムより計測した 最大の梗塞面積は組織学的な梗塞病変部位と最もよく 直線の相関関係を示した。

(120494)

(121844) 
7136 [4:A] Radionuclide Determination of Cardiac Chamber Flow/Volume Characteristics, G.S. Freedman, et al.: Yale Univ. Sch. Med. and Hosp., St. Raphael, New Haven, J. Nucl. Med., 17, (2) $84 \sim 87$ (1976)

胸壁外より測定した RI 希釈曲線の流量・体積曲線 は心臓各室の異常について有用な情報を提供する。シ ソチレーションカメラを用いてこの流量/体積比の測 定法について述べた。ここではとくに右心系の心障害 について検討を加えた。その理論を証明するために ${ }^{99 m} \mathrm{~T}$ c を用いて RI アンギオグラフィを施行した。患 者は RAO としボーラス注射によってデータを記録, 集積，分析した。

(121197)
7137 [4: A] Rat Model for Acute Myocardial Infarction: Application to Tc-Labeled Glucoheptonate, Tetracycline, and Polyphosphate, $\mathrm{N}$. Adler, et al.: New Eng. Nucl. Corp., Radiopharm. Div., North Billerica, J. Nucl. Med., 17, (3) 203 $\sim 07$ (1976)

ラットの心筋を焼灼して急性の心筋梗塞を作成して 臨床的な心筋梗塞のイメージ用薬物の価値を判定し た。このようにして作った心筋梗塞は人間に拈けるる のとよく相関することが知られている。結論として急 性心筋障害においてグルコヘプトネイトおよびポリフ ォスフェイトのよらなキレート剤が容易に取り込まれ ることが判明した。(戝表略)

(121772)
7138 [4 : A] Idiopathic Hypertrophic Subaortic Stenosis: Detection by ${ }^{201}$ Tl-Myocardial Perfusion Imaging, B.H. Bulkley, et al.: Johns Hopkings Sch. Med., Baltimore, N. Engl. J. Med., 293, (22) 1113〜16 (1975)

${ }^{201} \mathrm{Tl}$ による心筋シンチグラムを 10 名の特発性肥厚 性弁下狭窄症に施行した。非対称的な中隔の肥厚が本 疾患の特徵であるが ${ }^{201} \mathrm{Tl}$ シンチグラムは明瞭にこれ を示した。本症の患者では中隔の厚さの左室自由壁に 対する比は, 1.7であり正常人では1.0また求心性左室 肥大においても1.0であった。また肺高血圧症および 2 次性の非対称性中隔肥厚症においては右室壁厚が著 明に増加することによって大動脈弁下肥厚性狭窄症と 鑑別することができた。結論として ${ }^{201} \mathrm{Tl}$ シンチグラ ムは本症の疾患診断に有用である。

(120327)
7139 [5: A] Radionuclide Liver Scans in Tumor Detection, R.P. Spencer: Dept. Nucl. Med., Univ. Conn. Health Center, Farmington, Cancer, 37, (1) $475 \sim 79$ (1976)

悪性腫瘍の検索のための肝スキャンには種々のアプ ローチがあり，それを体系化し，秩序立てることを目 的とした。 ${ }^{99 m} \mathrm{~T} \mathrm{c}$ ーサルファコロイドによる動態像およ び静態像をおこない, 前者に異常があれば, 血液プー ルスキャン核種によりくり返し, 後者が異常であれば その原因を決定する目的で, 血流供給の有無は血液プ 一ルスキャン，胆管払張または胆のらであるかどらか

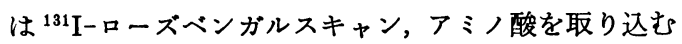
か否かは ${ }^{75} \mathrm{Se}$-セレノメチオニンスキャン, 腫痬親和 性核種の取り込みは ${ }^{87} \mathrm{Ga}$-citrate スキャンをおこな う。

(121298)
7140 [5: A] False-Positive Liver Scan Following Colectomy, T.K. Chaudhuri: VA Center, Hampton, JAMA, 234,' (7) 705 (1975)

正常肝が，異常スキャン像を呈した興味ある症例を 報告する。27歳, 男, クローン病と大腸がんで大腸切 除術を受けた。術前肝スキャンは正常であったが，術 後のスキャンで不均一なコロイド分布と局所欠損, 脾 摂取増加が見られ, 肝実質性病変と門脈圧方進が疑わ れた。しかし, 肝機能検査, 肝生検, 開腹術で肝が正 常であることが証明された。大腸切除により下腸間膜 静脈および，上腸間膜静脈の一部が，結紮され，門脈 血流の減少により肝へのコロイド運搬が減少し, 代償 性に脾への取込みが増加したと考えられる。

(120608)
7141 [5:A] Subtraction Scanning of Liver Metastases with ${ }^{67} \mathbf{G a}$ and ${ }^{99 m} \mathbf{T c}, M$. Erjavec, et al.: Inst. Oncol., Ljubljana, Yugoslavia, J. Nucl. Biol. Med., 19, (2) 53〜57 (1975)

肝転移巣の陽性画像を得る目的で, off-line コンピ ニータを用いて ${ }^{99 m} \mathrm{Tc}$-コロイドと ${ }^{67} \mathrm{Ga}$-citrate で 2 種シンチグラフィをおこなった。同時計数された 2 核 種のカウントの減算により, コロイドよりガリウムの 多く集積している部分の陽性像が得られる。他の方法 で確診を得た95例中，本法での正診は85例であった。 本法は従来のスキャンのあいまいな点を明らかにし， 良性疾患による異常所見を悪性疾患と区別するのに有 効であると思われる。しかし高分化型悪性腫瘍ではあ まり有効ではないよらだ。

（120686） 
7142 [5: A] Extrahepatic Lesions Causing FalsePositive Liver Scans, T.K. Chaudhuri: East. Vriginia Med. Sch. and VA Center, Hampton, Va. Med. Mon., 103, (2) 129 30, 135, 165 (1976)

${ }^{99 m}$ Tc-sulfur colloid による肝スキャンは肝内病巣 の診断法として有用であり，欠損または cold areaは 通常肝内空間占拠病变が原因となるが，肝外腫瘤によ る肝スキャン像の切れ込み, 偏位, 歪みなどの cold area について論じる。後腹膜腫瘤が肝スキャン欠損 像の原因となった 3 例で，全例，他の検査とは無関係 にスキャンで, 肝外腫瘤による右葉の圧排が疑われ た。手術の結果, 右腎巨大腫瘍 ( 2 例), 後腹膜神経芽 細胞腫( 1 例)が，右上腹部をほとんど占めていた。術 後肝スキャンでは欠損は認められず元来の位置に戻っ ていた。

(121527)
7143 [8: A] Specificity of ${ }^{131}$ I-19-Iodocholesterol Scintigraphy in Categorizing States of Adrenal Corticoid Excess, R.S. Hattner, et al.: Nucl. Med. Sect. and Metab. Res. Unit, Univ. Caif., San Francisco, Clin. Res., 24, (2) 100A (1976)

19-131I-iodocholesterol (19IC) による副腎シンチグ ラフィは，19IC の純化と品質の向上により，非侵襲 的手段による副腎検查法として広く用いられるよらに なっている。臨床的に，また生化学的所見から副腎皮 質ステロイド過剩産生が考えられる 9 例について, RI 投与 $5 \sim 9$ 日，10〜14日後に副腎シンチグラフィが行 われた。free ${ }^{131} \mathrm{I}$ の甲状腺集積をブロックするためル ゴール液が投与され，腎藏との位置関係を知るため ${ }^{99 m}$ Tc-gluconate による腎シンチグラフィが行われ た。手段所見とよく一致し副腎腫瘍の診断，治療方針 の決定に有用であった。

(121846)
7144 [8: A] Location of Aldosterone-Producing Adenomas with ${ }^{131}$ I-19-Iodocholesterol, $M$. J. Hogan, et al.: Clin. Study Center, San Francisco Gen. Hosp., N. Eng. J. Med., 294, (8) 410 14 (1976)

レニンーアンギオテンシンーアルドステロン系の異常

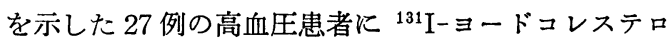
一ルによる副腎シンチグラフィを施行した。生化学的 検査よりアルドステロン産生腫湯の疑われた12例中10 例に副腎像の不整がみられ外科手術を行った 8 例の全 例に腺腫が証明された。原発性アルドステロン症, 低 レニン本態性高血圧症を疑われた13例中 1 例が副腎像 が不整を示した。2 例の副腎がんには放射能の集積は なかった。アルドステロン産生腫瘍の疑われるとき， ${ }^{131} \mathrm{I}$-ヨードコレステロールによる副腎シンチグラフィ は腫瘍の部位決めに有用と考えられた。

(121360)
$7145[8,11: \mathrm{Z}]$ A Comparison of the Clearance of Urographic Contrast Medium (Sodium Diatrizoate) by Peritoneal and Hemodialysis, $P$. Ackrill, et al.: Dept. Nephrol., St. Bartholomew's Hosp., London, Clin. Sci. Mol. Med., 50, (1) 69 $\sim 74$ (1976)

Diatrizoate $\mathrm{Na}$ 塩 (D-Na) を $\mathrm{RI}$ で標識し血液透 析によるクリアランス(C)を測定した。また同時に細胞 外液量も測定した。腹膜透析患者においても測定した。 また同時に尿素クリアランス（U-C）も测定した。血 液透析に拈いては D-Na と U-C は細胞外液あるいは 血漿量の透析期にふえるにつれて直線状に増加した。 他方 D-Na と U-C 比は減少した。D-Na の生体に拉 けるCはそれに相当する液量の体外に打けるよりる やや低かった。しかしながら D-Na と U-C 比は有意 な差を示さなかった。腹膜透析に特いては D-Na と U-Cは血液透析よりもはるかに低かった。(121872)
7146 [9:A] Ultrasound: Placental Localization: Radiographic, Radioisotopic, and Ultrasound Imaging, R.C. Brown, et al.: Appl. Radiol. Nucl. Med., 4, (41 5), 61, 64, 66 67 (1975)

種々の放射線的, 核医学的执よび超音波学的方法を 用いての胎盤の位置診断についての総説である。超音 波が最も選択すべき方法である。そしてそれは最も正 確であり障害は母子ともに示されていない。 RI は次 善の方法である。適当に用いれば正確である。被ばく 線量もそれほど多くはない。その両者もない場合には 胎盤造影が選択すべき方法と思われる。

(121183)
7147 [12:A] Peripheral Vascular Perfusion Scanning. Correlation with the Arteriogram and Clinical Assessment in the Patient with Peripheral Vascular Disease, M.E. Siegel, et al.: Div. Diagnostic Radiol., Johns Hopkins Med. Inst., Baltimore, Amer. J. Roentgenol., 125, (3) 628 33 (1975)

${ }^{99 m} \mathrm{~T} c$-ヒト血清アルブミンミクロスフェア（15一 $30 \mu$ 径) を下大動脈に急速注入をおこなった。つぎに 患者の下肢に特殊なストッキングをはかせ，患者の収 縮期圧よりも $50 \mathrm{mmHg}$ 高く保ら 5 分間おいた。これ をはずして，充血反応が最も強い時期に $5-10 \mathrm{mCi}$ の ${ }^{113 m}$ In 標識アルブミンミクロスフェアを再び静注し た。このような末梢血管の灌流シンチグラムは造影剂 による動脈造影あるいは臨床的所見とかならずしも一 致しない所見を呈した。従ってこの検査はそれらの検 查に対してさらに補助的に用いて臨床的に有用であ る。
(120712) 
7148 [12:A] Vertebral Artery Fistula Detected by Radionuclide Angiography: Case Report, J.F. Rockett, et al.: Baptist Memo. Hosp., Memphis, J. Nucl. Med., 17, (1) 24 25 (1976)

52歳の女性で主訴は左の耳なり。両側頸動脈に血管 性雑音がきかれた。シンチカメラを用いて ${ }^{99 m} \mathrm{Tc}$-pertechnetate $15 \mathrm{mCi}$ を静注し RI アンギオと脳シンチ をおこなった。その結果高速連続撮影シンチグラムに おいて頸部に放射能の增加を認め, 椎骨動静脈ろうが 発見された。右の椎骨動脈に $1.5 \mathrm{~mm}$ の動静脈ろうを 手術で確かめ結窄を知こなった。

(120579)
7149 [15: A] Localization of ${ }^{90 m}$ Tc-Pyrophosphate in Soft Tissue Malignancies, L.S. Richman. et al.: Dept. Radiol., Presbyterian Univ. Hosp., Pittsburgh, Amer. J. Roentgenol. Radium Ther. Nucl. Med., 124, (4) 577 82(1975) 軟部組織の悪性腫瘍 5 症例にスキャニングにより ${ }^{99 m} \mathrm{~T}$ c-ポリリン酸の集積を認めた。マウスのP 1798 固 型リンパ腫にるこの RI は摂取される。軟部組織腫場 への ${ }^{{ }^{9 m} \mathrm{~T}} \mathrm{~T} \mathrm{c}$-ポリリン酸集 積の機序は明確でないが, 非特異性の機序が考えられる。

(119058)
7150 [15:A] Accumulation of ${ }^{99 m}$ Tc-Diphosphonate in Malignant Pleural Effusions: Detection and Verification, M.E. Siegel, et al.: Malcolm Grow USAF Med. Center, Andrews Air Force Base, Wash., J. Nucl. Med., 16, (10) 883 85 (1975)

2 例のがん性胸水に ${ }^{99 m} \mathrm{Tc}$-diphosphonate の集積 像が得られた。第 1 例は 52 歳男性, 左気管支がんで骨 スキャンを行ったところ, 左後胸郭部にび漫性の集積 像があったが, 骨破壊はなかった。胸部X線像では左 胸水を認め穿刺 $150 \mathrm{cc}$ 中に悪性細胞が見られた。第 2 例は50歳女性，右乳がん手術後に骨スキャンを行った ところ左後胸郭部にび漫性の集積像があった。胸部X 線像では左胸水を認めた。30時間後再度スキャンを行 っても同様であり, $2 l$ の胸水穿刺夜中に悪性細胞を 認めた。

(119098)
7151 [15: A] Bilateral Breast Uptake of ${ }^{99 m} \mathbf{T c}$ Polyphosphate in a Patient with Metastatic Adenocarcinoma, M.M. Shultz, et al.: Dept. Radiol., Phil. Gen. Hosp., Radiology, 118, 377 78 (1976)

41 歳婦人で, 直腸の腺がんの乳房転移巣に ${ }^{99 m} \mathrm{Tc}$ polyphosphate がとりこまれた。

転移部に石灰化の徵候はみられなかった。

(121060)
7152 [30:A] ${ }^{67}$ Ga-Citrate Scans in Febrile Patients, M.R. Habilban, et al.: Div. Nucl. Med., Univ. North Carolina, Chapel Hill, JAMA, 233, (10) $1073 \sim 76$ (1975)

${ }^{67} \mathrm{Ga}$-クエン酸のスキャンは炎症病巣の 発見に役立 つ。22例の発熱症例中 17 例は 1 つ以上の ${ }^{67} \mathrm{Ga}$ 異常集 積を示した。 8 例では，炎症巣に集積したが，5例で はスキャン部位には炎症巣はなかった。 ${ }^{67} \mathrm{Ga}$ は発熱 の原因が不明の場合にその解明に役立つ。

(118905)
7153 [30: C] Localization of Occult Abscesses Utilizing Radioactive Fibrinogen, J.C. Parodi, et al.: Chicago, Il., Ill. Med. J., 148, (2) 142 45 (1975)

${ }^{131} \mathrm{I}$ 一標識 $ィ$ ブリノーゲンを用いて膿湟の部位診断 を行らことを目的として研究を実施した。脤場壁には フィブリンが沈着するが，その量は必ずしも一定して いない。膿湟部は心臓部よりる高い放射能を示した。 排腰部は110～369\%（平均189\%）の放射能であった。 膿場が疑われた症例中，100\%以下の放射能を示した 13例はのちに脹湯に発展しなかったが，103〜355\%の 放射能を示した12例は全例に膿場が見られた。

(118875) 
629 Radioimmunoassay for L-3, 3', 5'-Triiodothyronine (Reverse $\mathrm{T}_{3}$ )

H. Meinhold, et al.: Acta Endocrinol., 80, (Suppl. 199) 343 (1975)

630 Brain Imaging

L.D. Greenfield, et al.: Am. Fam. Physician, 13, (4) 95-102 (1976)

631 Parameters of Liver Spleen Scans as an Indication of Portal Hypertension

G. Davis, et al.: Am. J. Gastroenterol, 65, 31-36 (1976)

632 Bone Marrow ${ }^{99 m}$ Tc-Sulfur Colloid Distribution and Marrow Cellularity

R.E. Henry, et al.: Am. J. Med. Sci., 270, (3) 419-25 (1975)

633 Bone Tumor Imaging by Scintigraphy of the Skeleton, Marrow Reticuloendothelial System, and the Proliferative Tissue

S. Okuyama, et al.: Am. J. Roentgenol. Radium Ther. Nucl. Med., 125,(4)965-71(1975)

634 Accuracy of ${ }^{99 m}$ Tc-Diphosphonate Bone Scans and Roentgenograms in the Detection of Prostate, Breast and Lung Carcinoma Metastases J.D. Osmond, III, et al.: ibid., 125, (4) 972-77 (1975)

635 Bone Scintiscanning Updated

B.C. Lentle, et al.: Ann. Intern. Med., 84, (3) 297-303 (1976)

636 Bone Marrow Scan Evaluation of Arthropathy in Sickle Cell Disorders

A. Alavi, et al.: Arch. Intern. Med., 136,(4) 436-40 (1976)

637 Arthroscintigraphy with Technetium Albumin in Diagnosis of Pseudophlebitis(Baker's Cyst) A.E. Watkins, et al.: Brit.Med. J., 4, (5988) 86 (1975)

638 Kidney Depth Measurements Using a Double Isotope Technique

S.T. Ostrowski, et al.: Excerpta Med. Sect. 23, Nucl. Med., 17, (1) 78 (1976)

639 Kidney Position and the Measurement of Relative Uptake of ${ }^{131} \mathrm{I}$-Hippuran in Renography

C.C. Nimmon, et al.: ibid., 17, (1) 78 (1976)

640 The Application of the ${ }^{99 m} \mathrm{Tc}-\mathrm{Phosph}$ ate Bone Scan to the Study of Breast Cancer

D.L. Citrin, et al.: ibid., 17, (1) 80-81(1976)

641 Optimal Scanning Time with Technetium$99 m$ Labelled Bone Agents

F.T.A. Lovegrove, et al.: ibid., 17, (2) 131 (1976)
642 Ocular Scintigraphy

Rh. Verin, et al.: ibid., 17, (2) 132 (1976)

643 The Value of ${ }^{131}$ I-Labeled Albumin Macroaggregated in the Localization of Intra-Arterial Chemotherapy for the Treatment of Advanced Cancer of the Head and Neck

A. Rapoport, et al.: ibid., 17, (2) 135 (1976)

644 Location of Brain Neoplasms when EEG is Normal

E.V. Spudis, et al.: ibid., 17, 357 (1976)

645 Radioisotope Cisternography in Head Injured Patients

R. Villani, et al.: ibid., 17, (5) 357-8 (1976)

646 Serum Ferritin, Iron Stores, and Iron Metabolism

F.L.A. Willekens: ibid., 17, (5) 377 (1976)

647 Bone Marrow Scanning

M. Salvatore, et al.: ibid., 17, (6) 434 (1976)

648 Diagnostic Value of Brain Scanning in the Pediatric Age Group

H. Hiratsuka, et al.: ibid., 17, (7) 510 (1976)

649 Measurement of Renal Circulation Using Isotope Dilution Technique after Selective Arterial Injection of ${ }^{99 m} \mathrm{Tc}-$ Pertechnetate M. Oberdorfer, et al.: ibid., 17,(7) 525(1976)

650 Liver Scanning in Diffuse Liver Disease P. Aiginger, et al.: ibid., 17, (7) 525 (1976)

651 Determination of Glomerular Filtration Rate and Renal Plasma Flow in Children with a Single Injection of Radionuclides

J. Simon, et al.: ibid., 17, (9) 698 (1976)

652 An Analysis of Factors which Influence the Local Accumulation of Bone-Seeking Radiopharmaceuticals

E.S. Garnett, et al.: Invest, Radiol., 10, (6) 564-68 (1975)

653 Focal Bone Pain: Infection or Infarction?

L.G. Lutzker, et al.: JAMA, 235, (4) 425-6 (1976)

654 Thyroid Scintigram. Sensitivity with Sodium Pertechnetate Tc-99m and Gamma Camera with Pinhole Collimator

U.Y. Ryo, et al.: ibid., 235,(12)1235-8(1976)

655 Single Subcutaneous Injection of Iothalamte Sodium ${ }^{125} \mathrm{I}$ to Measure Glomerular Filtration Rate

P.Y. Adefuin, et al.: ibid., 235, (14) 1467 $\sim 69$ (1976)

656 Diagnosis of Mekel Diverticulum by Sodium Pertechnetate Tc-99m Scan

M. Cooper, et al.: ibid., 235, 1471-72 (1976) 
657 Pharmacokinetics of ${ }^{125} \mathrm{I}$-Iothalamate and ${ }^{131} \mathrm{I}$ -o-Iodohippurate in Man

P.G. Welling, et al.: J. Clin. Pharmacol., 16, (2/3) 142-8 (1976)

658 A Comparison of in vitro Methods in the Assessment of Thyroid Status

T.M.D. Gimlette, et al.: J. Nucl. Biol. Med., 19, (3) 155-61 (1975)

659 Relative Accretion of ${ }^{90 m} \mathrm{Tc}$-Polyphosphate by Forming and Resorbing Bone Systems in Rats: Its Significance in the Pathologic Basis of Bone Scanning

D.A. Garcia, et al.: J. Nucl. Med., 17, (2)93 -97 (1976)

660 Comparison of ${ }^{18} \mathrm{~F}$ and ${ }^{99 m} \mathrm{Tc}$-Polyphosphate in Orthopedic Bone Scintigraphy

J. Heerfordt, et al.: ibid., 17,(2)98-103(1976)

661 Increased Localization of ${ }^{99 m} \mathrm{Tc}-\mathrm{Py}$ rophosphate in a Bone Island: Case Report E.A. Sickles, et al.: ibid., 17,(2)113-15(1976)

662 Inadvertent ${ }^{131} \mathrm{I}$-Therapy for Hyperthyroidism in the First Trimester of Pregnancy S.S. Stoffer, et al.: ibid., 17,(2) 146-9 (1976)

663 Serial Bone-Scan Changes in Recurrent Bone Infarction

N.D. Greyson, et al.: ibid., 17,(3)184-6(1976)

664 Osteoblastomas of the Axial Skeleton Shown by Skeletal Scanning: Case Report

N.L. Martin, et al.: ibid., 17,(3)187-89(1976)

665 Comparison of Inulin, Iothalamate, and ${ }^{99 \mathrm{~m}} \mathrm{Tc}$ -DTPA for Measurement of Glomerular Filtration Rate

G.L. Barbour, et al.: ibid., 17, 317-20 (1976)

666 The ${ }^{99 m}$ Tc-DTPA Dynamic Renal Scan with Deconvolution Analysis

B.L. Diffey, et al.: ibid., 17,(5) 352-55(1976)

667 Diagnosis of Hepatic Hemangioma Using Multiple-Radionuclide and Ultrasound Techniques

R.D. Taylor, et al.: ibid., 17,(5) 362-64(1976)

668 Arteriographically Confirmed Focal Defect in Colloid Spleen Scan with no Gross Pathologic Lesion: Case Report

C.D. Russell, et al.: ibid., 17,(5)376-77(1976)

669 Usefulness of Brain Scans in Metastatic Carcinoma of the Lung

J.F. Delaney, et al.: ibid., 17, (5) 406-7 (1976)

670 Focally Increased Activity on Scinticisternography: Report to Two Cases

R.R. McClelland: ibid., 17, (7) 626-29 (1976)

671 The Value of Radioisotope Renogaphy in the
Followup of Patients Operated upon for $\mathrm{Hy}$ dronephrosis

K.J. Tveter, et al.: J. Urol., 114, (5) 680-83 (1975)

672 Evaluation of Radiography and Isotopic Scintigraphy for Detecting Skeletal Metastases in Breast Cancer

J.G. Roberts, et al.: Lancet, 1, (7953) 237-9 (1976)

$673{ }^{99 m}$ Tc-Pyrophosphate Bone Scans and Endocrinologic Evaluation in a Patient with Eosinophilic Granuloma

J.W. Plonk, et al.: N.C. Med. J., 36,(10)605 -06 (1975)

674 Multiple-Myeloma Bone Disease. The Comparative Effect of Sodium Fluoride and Calcium Carbonate or Placebo

R.A. Kyle, et al.: N. Engl. J. Med., 293,(26) 1334-8 (1975)

675 Specific Diagnosis of Brain Disease with Double Isotope Brain Scanning

P.J. Ell, et al.: Nucl. Med., 15, (1) 32-35 (1976)

676 Diagnosis of Meckel's Diverticulum by $\mathrm{Ra}$ dioisotope Scanning

G.I. Martin, et al.: Pediatrics, 57, (1) 11-12 (1976)

677 Unified Radiological Approach to the Detection of Skeletal Metastases

J.C. Mall, et al.: Radiology, 112, (2) 323-8 (1976)

678 Radionuclide Imaging the Bones and Joints of the Hand

C. Bekerman, et al.: ibid., 118,(3)653-59(1976)

679 Determination of Fractional Renal Function in Renography with and without Individually ${ }^{131}$ I-Albumin-Determined Blood Backgound M. Stockel, et al.: Scand. J. Clin. Lab. Invest., 35, (6) 511-15 (1975)

680 The Diagnostic Value of Liver Scanning. A Retrospective Study

H. Andersen, et al.: Scand. J. Gastroenterol., 11, (3) 241-8 1976)

681 Technetium Stannous Pyrophosphate Myocardial Scintigraphy for Diagnosing and Localizing Acute Myocardial Infarcts

J.T. Willerson, et al.: Tex. Med., 72,(2) 616 (1976)

682 The Detection of Deep Venous Thrombosis Using Labelled Urokinase

W.T. Millar, et al.: Thromb. Diath. Haemorrh., 34, (3) 904 (1975) 